\title{
Melatonin protects skin keratinocyte from hydrogen peroxide- mediated cell death via the SIRT1 pathway
}

\author{
Ju-Hee Lee ${ }^{1}$, Ji-Hong Moon ${ }^{1}$, Uddin MD. Nazim ${ }^{1}$, You-Jin Lee ${ }^{1}$, Jae-Won Seol ${ }^{1}$, \\ Seong-Kug Eo' ${ }^{1}$, John-Hwa Lee ${ }^{1}$ and Sang-Youel Park ${ }^{1}$ \\ ${ }^{1}$ Biosafety Research Institute, College of Veterinary Medicine, Chonbuk National University, Jeonju, Korea \\ Correspondence to: Sang-Youel Park, email: sypark@chonbuk.ac.kr \\ Keywords: melatonin, autophagy, hydrogen peroxide, keratinocyte, Pathology Section \\ Received: August 05, $2015 \quad$ Accepted: February 13, $2016 \quad$ Published: February 24, 2016
}

\section{ABSTRACT}

Melatonin ( $\mathrm{N}$-acetyl-5-methoxytryptamine), which is primarily synthesized in and secreted from the pineal gland, plays a pivotal role in cell proliferation as well as in the regulation of cell metastasis and cell survival in a diverse range of cells. The aim of this study is to investigate protection effect of melatonin on $\mathrm{H}_{2} \mathrm{O}_{2}$-induced cell damage and the mechanisms of melatonin in human keratinocytes. Hydrogen peroxide dose-dependently induced cell damages in human keratinocytes and cotreatment of melatonin protected the keratinocytes against $\mathrm{H}_{2} \mathrm{O}_{2}$-induced cell damage. Melatonin treatment activated the autophagy flux signals, which were identified by the decreased levels of p62 protein. Inhibition of autophagy flux via an autophagy inhibitor and ATG5 siRNA technique blocked the protective effects of melatonin against $\mathrm{H}_{2} \mathrm{O}_{2}$-induced cell death in human keratinocytes. And we found the inhibition of sirt1 using sirtinol and sirt1 siRNA reversed the protective effects of melatonin and induces the autophagy process in $\mathrm{H}_{2} \mathrm{O}_{2}$-treated cells. This is the first report demonstrating that autophagy flux activated by melatonin protects human keratinocytes through sirt1 pathway against hydrogen peroxide-induced damages. And this study also suggest that melatonin could potentially be utilized as a therapeutic agent in skin disease.

\section{INTRODUCTION}

$\mathrm{H}_{2} \mathrm{O}_{2}$ isobserved in nearly all types of oxidative stress and oxygen radicals, spreads freely within and beyond cells and tissues [1] and has the ability to modulate various signal transduction pathways $[2,3]$. When in an environment with keratinocytes, $\mathrm{H}_{2} \mathrm{O}_{2}$-induced cell damage [4] can include early apoptosis and oxidative stress. Beyond this, $\mathrm{H}_{2} \mathrm{O}_{2}$, which is generated in the skin as a response to $\mathrm{UV}$ radiation, is capable of inducing lipid peroxidation, protein modification and DNA damage [5] as well as producing oxygen radicals that cause direct oxidative stress in human keratinocytes [6]. $\mathrm{H}_{2} \mathrm{O}_{2}$-induced oxidative stress in keratinocytes can trigger many skin diseases, including vitiligo [5], skin cancer and advanced skin aging [7]. Consequently, these processes have drawn considerable attention in the dermatology field.

Melatonin,N-acetyl-5-methoxytryptamine, is a lipophilic molecule that is mainly synthesized in the pineal gland and functions as a ubiquitous physiological mediator [8]. It has been found in a diverse array of tissues, including the intestine, thymus, gastrointestinal tract [9], eyes [10], kidneys [11], lungs [12], skin [13] and immune system [14], among others, with most of these tissues expressing melatonin-synthesizing enzymes [15-17]. Numerous studies have recognized melatonin as an important factor in protective effects, including the regulation of circadian rhythms, the reduction of cancer or other metastatic diseases, and increased anti-inflammatory properties and function of free radical scavenger as well as cell proliferation [18-22] in many different cells [23, 24]. In human keratinocytes, melatonin and its metabolites [25] play a pivotal role in protecting several vital physiological and pathological processes [26] and regulating immune and endocrine functions [27]. It also has many other effects by acting as a hormone, neurotransmitter, cytokine and biological modifier [28]. Additionally, melatonin exhibits protective effects on $\mathrm{H}_{2} \mathrm{O}_{2}$-induced cytotoxicity [29] and has been identified as a regulator of autophagy $[30,31]$ in mTOR-dependent pathways [32].

Autophagy is recognized as the cellular response involved in maintaining homeostasis and defending against infection [33]. This response also triggers antigen presentation [34],embryogenesis [35], development 
[36] and metabolism [33] through the degradation of unnecessary and long-lived proteins, cytosolic components, mitochondria [37], macromolecules, and damaged organelles [38]. One such protein is sequestosome-1, p62, a molecular adapter that interfaces between autophagic machinery and its substrates $[39,40]$. The degradation process is initiated by generating doublemembrane organelles, which then lead to the formation of autophagosomes. Subsequently, the autophagosomes fuse with lysosomes to form autolysosomes, where components are then digested [41, 42]. This process leads to the recycling of components back into the cytoplasm [43]. Autophagy, which is constitutively induced in response to basal level environmental signals, is a very important function because it maintains cellular quality in protein conformational disorders and promotes rapid adaptation to microenvironmental changes [44-46].

Silent information regulator 1 (Sirt1), a NADdependent class III histone deacetylase is a type of histone deacetylase [47, 48]. Sirt1 has an influence on keratinocytes, adipocyte, muscle, liver, and endocrine pancreas physiology [49-54]. Sirt1 in those tissues plays a key role in the longevity effects elicited by calorie restriction $[55,56]$. And also modulation of sirt 1 activity implicated in signaling networks, regulating cell metabolism, cellular senescence, endocrine signaling, stress responses and controlling cell death and survival $[51,52,57,58]$. In addition, sirt1 has been shown to inhibit cell differentiation in white adipocytes [59] and keratinocytes [53]. As cellular targets for sirt1, there are acetylated p53 [57, 58], p300, Ku70 [60] forkhead (FOXO) transcription factors [61, 62],PPAR $\gamma$ [50] and PPAR $\gamma$ coactivator-1 $\alpha$ (PGC-1 $\alpha)$ protein [51]. Deacetylation of p53 transcription factors and FOXO inhibits cell damage including apoptosis and enhances the cell survival signal $[58,60,62]$. Also it is known that melatonin can induce the increase of sirt1, which then leads to the deacetylation and subsequent inhibition of p53. However, the role of sirt1 in the protective effect of melatonin against $\mathrm{H}_{2} \mathrm{O}_{2}-$ induced keratinocyte death has not been explored.

Previous studies have reported melatonin's role in inducing autophagy [30,63]; however, no investigation has taken place regarding melatonin's possible role in regulating the sirt1/autophagy process in keratinocytes. The present study demonstrates that melatonin enhances the autophagy process as a primary mechanism through sirt1 activation in protecting keratinocytes against hydrogen peroxide-induced cell damage. These results suggest that melatonin may play a pivotal role as a therapeutic target for skin disease.

\section{RESULTS}

$\mathrm{H}_{2} \mathrm{O}_{2}$ 's relationship to cell damage in human keratinocytes is well known $[64,65]$ and results from the present study confirmed this. HaCaT keratinocytes were exposed to $\mathrm{H}_{2} \mathrm{O}_{2}$ for $18 \mathrm{~h}$, after which we confirmed cell morphology and cell number using a microscope (Figure $1 \mathrm{~A})$ and assessed cell viability using crystal violet assay (Figure 1B). Following the $\mathrm{H}_{2} \mathrm{O}_{2}$ treatment, we observed a gradual decrease in the number of cells as well as decreases cell survival rates. Consistent with these results, LDH activity increased in the presence of $\mathrm{H}_{2} \mathrm{O}_{2}$ (Figure 1C).

Recent studies have demonstrated that melatonin can facilitate preventive effects $[66,67]$ in keratinocytes and reduce cell damage related to the oxidative stress of hydrogen peroxide in human keratinocytes [68], but the effects of melatonin on hydrogen peroxide-induced cell death are unclear. Thus, we examined the preventive effects of melatonin against $\mathrm{H}_{2} \mathrm{O}_{2}$-induced cell death. $\mathrm{HaCaT}$ keratinocytes were pre-treated with melatonin at concentrations of $2.5,5$ and $10 \mu \mathrm{M}$ for $12 \mathrm{hr}$ and then exposed to $\mathrm{H}_{2} \mathrm{O}_{2}$ for $18 \mathrm{hr}$. After this, we confirmed cell morphology and cell numbers using a microscope (Figure 1D). And Cell viability also showed that melatonin prevented $\mathrm{H}_{2} \mathrm{O}_{2}$-induced cell death (Figure 1E). Moreover, increases in the $\mathrm{LDH}$ activity of $\mathrm{H}_{2} \mathrm{O}_{2}$-treated keratinocytes were gradually decreased with melatonin (Figure $1 \mathrm{~F}$ ).

Many studies have reported that melatonin increases autophagy [69] and that induction of autophagy is responsible for protective mechanisms in various cells. Therefore, we sought to verify whether melatonin influenced $\mathrm{H}_{2} \mathrm{O}_{2}$-induced cell death via autophagy. To clarify the mechanisms behind melatonin, we first examined the effects of melatonin treatment on the conversion of LC3-I to LC3-II. HaCaT keratinocytes treated with $1,2.5,5,10 \mu \mathrm{M}$ of melatonin for $24 \mathrm{hr}$ were subjected to Western blot analysis and the conversion of LC3-I to LC3-II and p62 protein levels were analyzed. We found a gradual increase in LC3-II expression and p62 degradation in melatonin-treated cells. A density graph of protein levels in p62 also reflected dose-dependent changes (Figure 2A). Immunocytochemistry demonstrated decreased p62 immunoreactivity in melatonin-treated keratinocytes as compared to the control (Figure 2B).

To determine the impact of melatonin-induced autophagy on $\mathrm{H}_{2} \mathrm{O}_{2}$-linked cell death in $\mathrm{HaCaT}$ keratinocytes, we blocked autophagy using the autophagy inhibitors 3-Methyladenine (3MA) and chloroquine (CQ). $\mathrm{HaCaT}$ keratinocytes pre-treated with autophagy inhibitor for $1 \mathrm{~h}$ were exposed to melatonin $10 \mu \mathrm{M}$ in the presence of $\mathrm{H}_{2} \mathrm{O}_{2}$. On crystal violet assay and LDH assay, cells treated with melatonin in the presence of $3 \mathrm{MA}$ and $\mathrm{CQ}$ displayed significantly decreased cell viability compared to treated melatonin treatment with $\mathrm{H}_{2} \mathrm{O}_{2}$ (Figure $2 \mathrm{C}$ and 2D). In Figure 2E, we examined the decreased LDH activities released to media by melatonin against $\mathrm{H}_{2} \mathrm{O}_{2}$ were restored by autophagy inhibitors. Treatment with 3MA and CQ did not cause any adverse effects on cell viability (data not shown). HaCaT keratinocytes treated with $10 \mu \mathrm{M}$ of melatonin in the presence of $3 \mathrm{MA}$ and $\mathrm{CQ}$ 
for $24 \mathrm{hr}$ were subjected to Western blot analysis, after which LC3-I to LC3-II conversion and p62 protein levels were analyzed. According to these protein levels, 3MA blocked melatonin-enhanced conversion of LC3-I to LC3II and reduced p62 degradation, respectively, and CQ also decreased p62 protein levels (Figure 2F). And also p62 immunoreactivity reduced by melatonin was restored in CQ-pretreated keratinocytes (Figure 2G).

We then sought to determine whether the inhibition of autophagy using ATG5 siRNA influences melatonin's

A
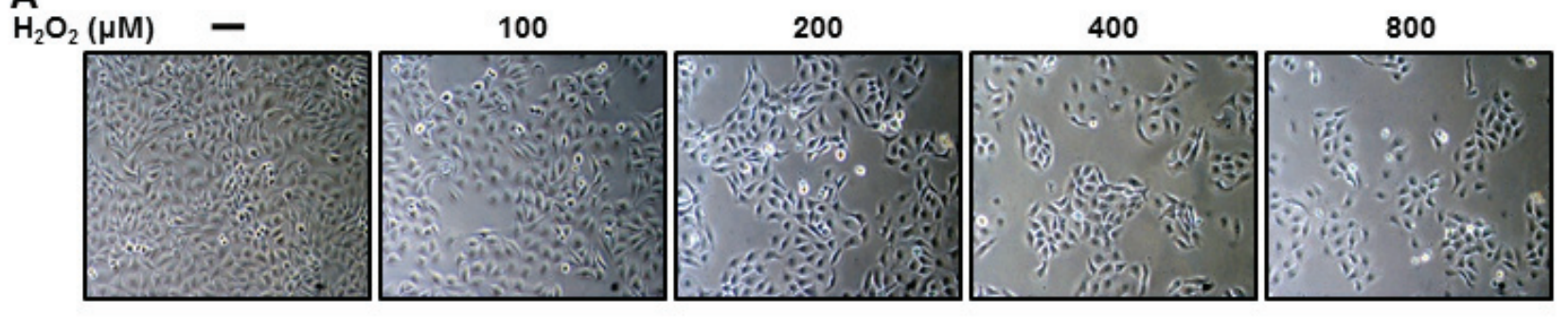

B

C
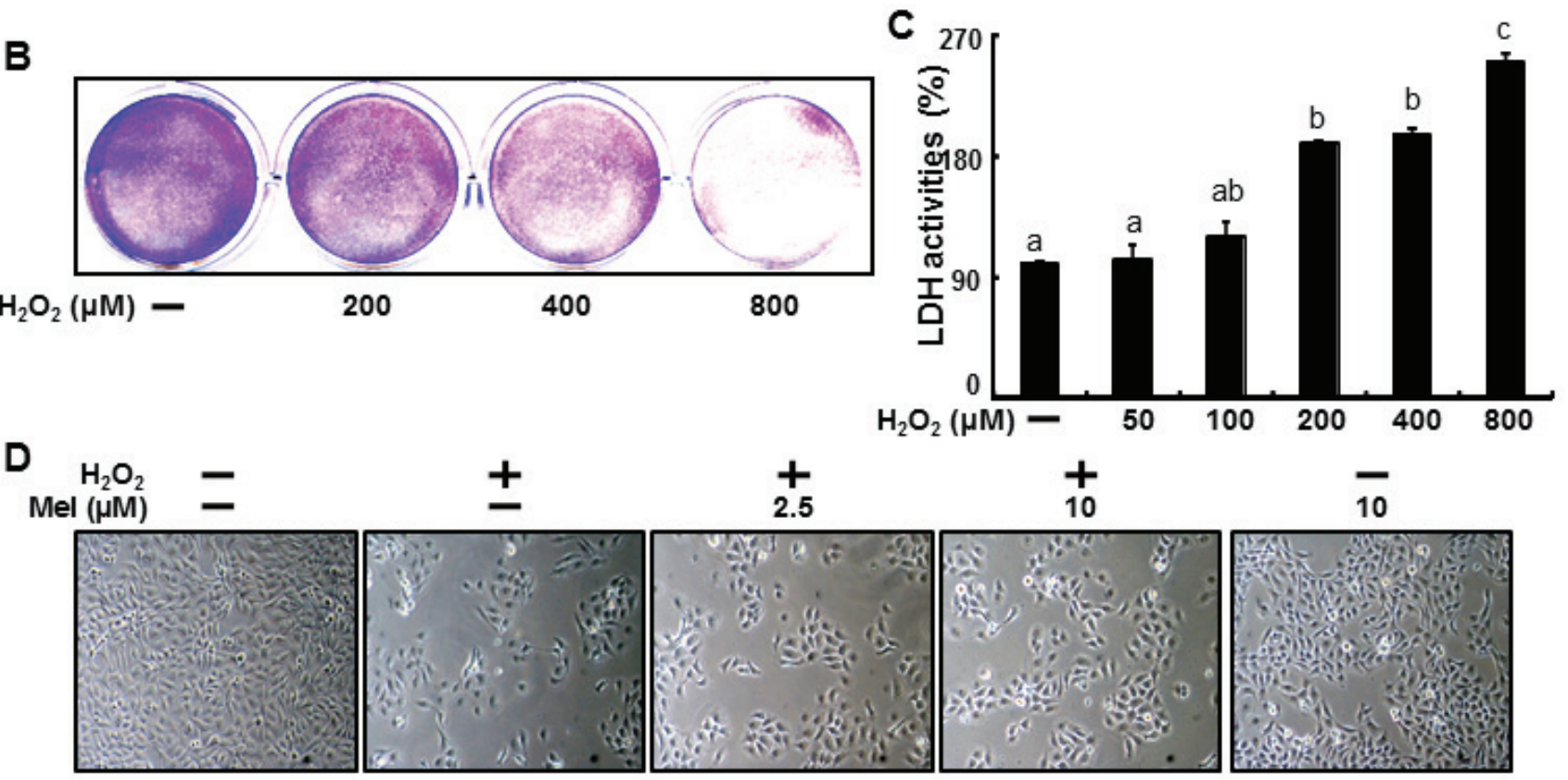

E
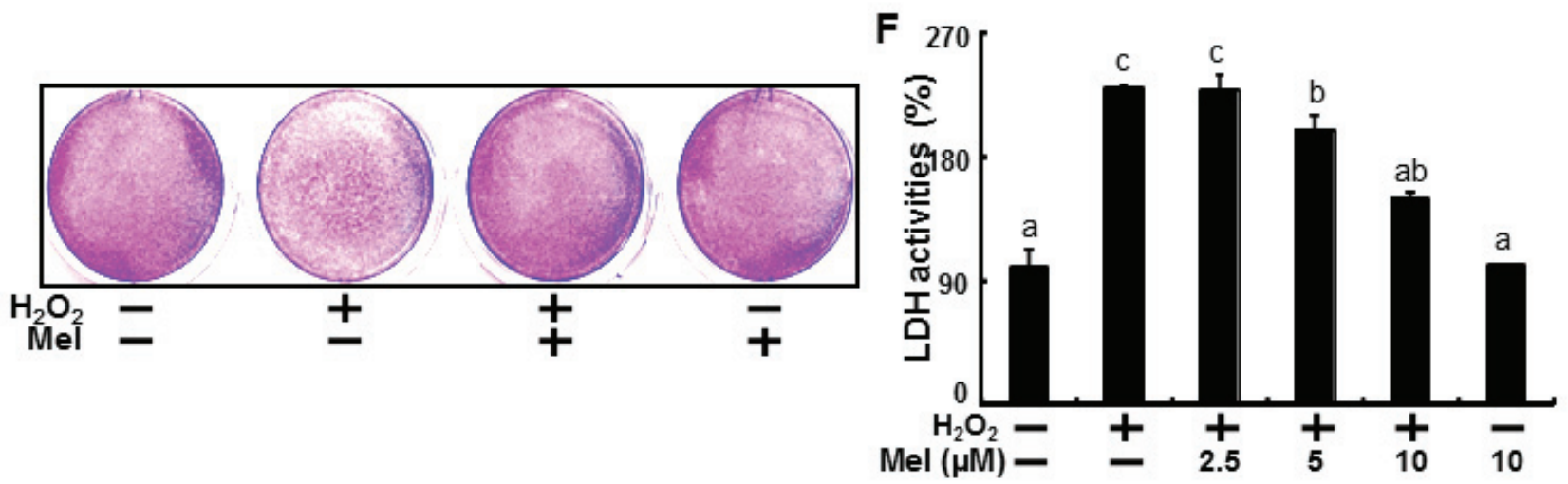

Figure 1: Melatonin prevents hydrogen peroxide-induced human keratinocyte cell death. HaCaT keratinocytes were exposed to 100, 200, 400 and $800 \mu \mathrm{M}$ of $\mathrm{H}_{2} \mathrm{O}_{2}$ for $18 \mathrm{hr}$. Treated cells were photographed using light microscopy A. and cell viability was measured via crystal violet staining. Viability of the control cells was set at $100 \%$ and viability relative to the control was measured B.. LDH activity was measured by quantifying LDH released in the medium C. HaCaT keratinocytes were pretreated with melatonin $(2.5,5$, and $10 \mu \mathrm{M}$ ) for $12 \mathrm{hr}$ and exposed to $800 \mu \mathrm{M}$ of $\mathrm{H}_{2} \mathrm{O}_{2}$, for $18 \mathrm{~h}$. Treated cells were photographed using light microscopy $\mathbf{D}$. and cell viability was measured via crystal violet staining. Viability of the control cells was set at $100 \%$ and viability relative to the control was measured E.. LDH activity was measured by quantifying LDH released in the medium $\mathbf{F}$. The data were analyzed using ANOVA and Tukey multiple range tests $(P<0.01)$. Means sharing a common alphabetical symbol did not significantly differ. 
A

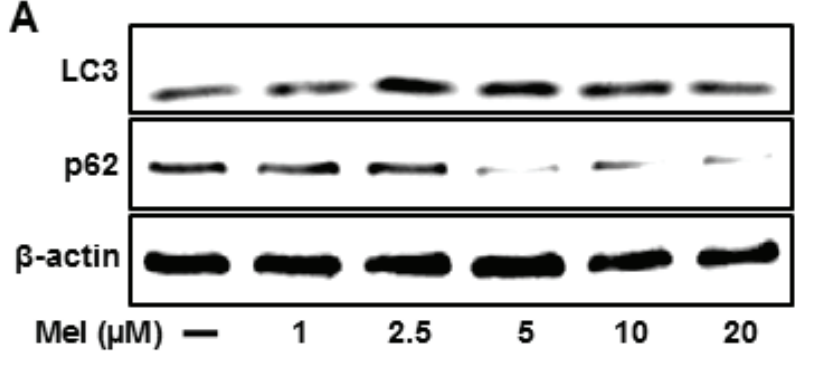

B

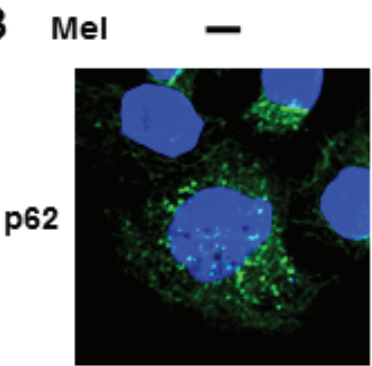

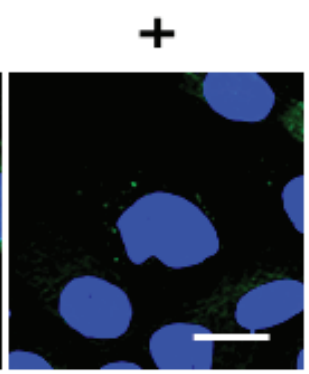

C
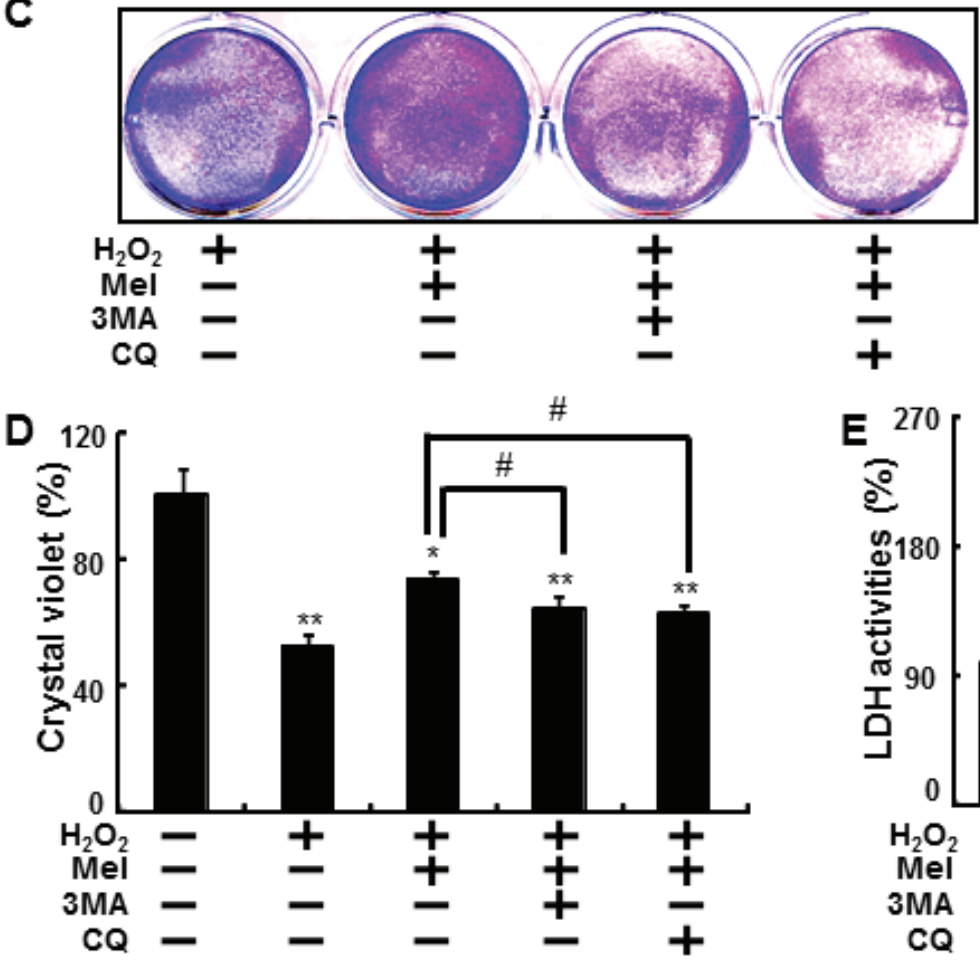

$\stackrel{+}{+}$

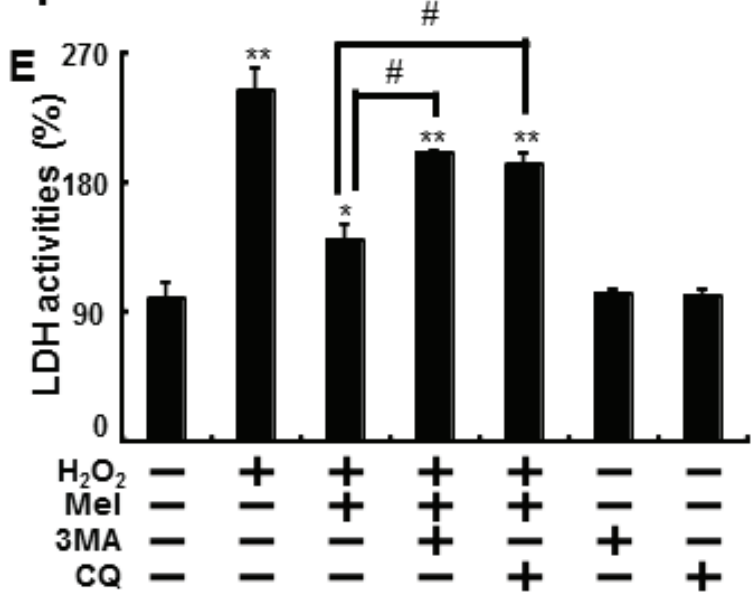

$\mathbf{F}$
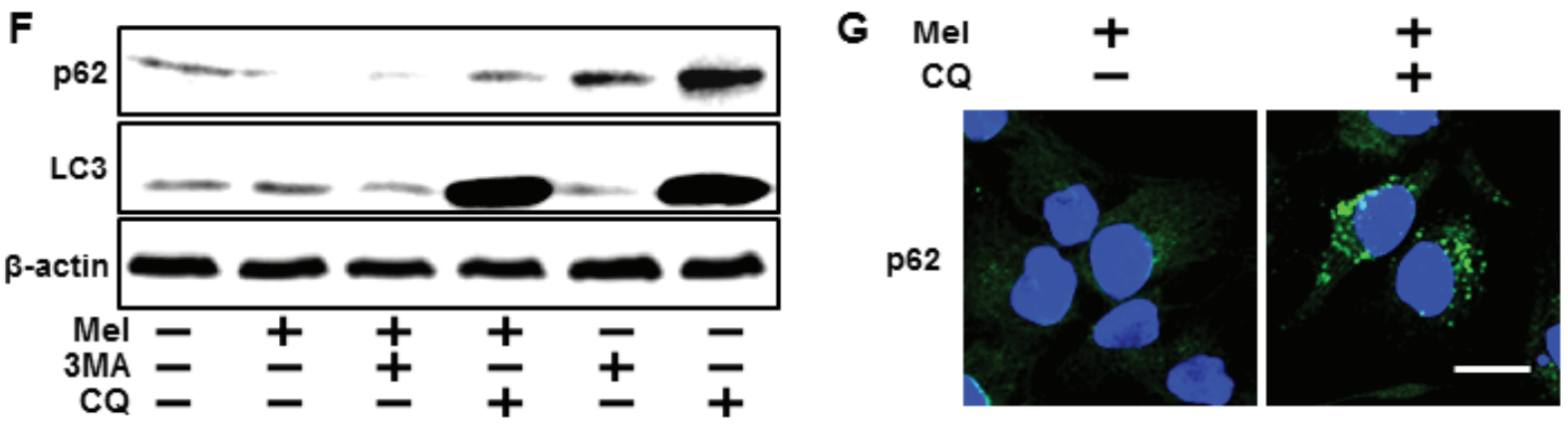

Figure 2: Melatonin-induced autophagy prevents the hydrogen peroxide-mediated human keratinocytes damage. $\mathrm{HaCaT}$ keratinocytes were treated with melatonin at different concentrations $(1 \sim 20 \mu \mathrm{M})$ with or without $\mathrm{H}_{2} \mathrm{O}_{2}(800 \mu \mathrm{M})$ for $24 \mathrm{hr}$. Western blot analysis of LC3-II and p62 proteins was conducted from the HaCaT keratinocytes A.. The melatonin-treated cells were immunostained with DAPI (blue) and p62 antibody (green) and fluorescence was examined B.. HaCaT keratinocytes were pretreated with melatonin (10 $\mu \mathrm{M})$ for $12 \mathrm{hr}$ in the presence of autophagy inhibitors, 3MA $(1 \mathrm{mM})$ and CQ $(10 \mu \mathrm{M})$, and then exposed to $800 \mu \mathrm{M}$ of $\mathrm{H}_{2} \mathrm{O}_{2}$ for $18 \mathrm{hr}$. Cell viability was measured using crystal violet staining. Viability of the control cells was set at $100 \%$ and viability relative to the control was measured C. D. . LDH activities were measured by quantifying LDH released in the medium E.. HaCaT keratinocytes were pretreated with melatonin $(10 \mu \mathrm{M})$ in the presence of 3MA $(1 \mathrm{mM})$ and CQ $(10 \mu \mathrm{M})$ and then exposed to $800 \mu \mathrm{M}$ of $\mathrm{H}_{2} \mathrm{O}_{2}$ for $12 \mathrm{~h}$. Western blot analysis of LC3-II and p62 proteins was conducted from the HaCaT keratinocytes. $\beta$-actin was used as the loading control F. HaCaT keratinocytes were analyzed by immunocytochemistry for p62 G.. The cells were immunostained with p62 antibody (green) and observed in the fluorescent view. Scale bar: $10 \mu \mathrm{m}$. The bar graph indicates the mean \pm standard error of the mean $(\mathrm{SEM})(n=4)$. ${ }^{*} p<0.05$ and $* * p$ $<0.01$, represent significant differences between the control and each treatment group and $\# p<0.01$; significantly different when compared with $\mathrm{H}_{2} \mathrm{O}_{2}$ and melatonin-treated group. 
protective effects against hydrogen peroxide. Results from the crystal violet staining indicate that the knockdown of autophagy by ATG5 siRNA significantly increased cell death (Figure $3 \mathrm{~A}$ and $3 \mathrm{~B}$ ). In the same manner, the knockdown of ATG5 enhanced LDH activity, which was reduced by melatonin (Figure 3C). LC3-II proteins increased as a result of melatonin were reduced and decreased p62 levels due to melatonin were restored to control conditions, where the cell was transfected to ATG5 siRNA (Figure 3D). In the same manner, ICC showed the silencing ATG5 using ATG5 siRNA restored the melatonin-induced $\mathrm{p} 62$ reduction to control condition (Figure 3E). These data indicated that the knockdown of ATG5 expression blocks melatonin's protective effects, which inhibits human keratinocyte damage.

The effect of melatonin on sirt1, which are known
A

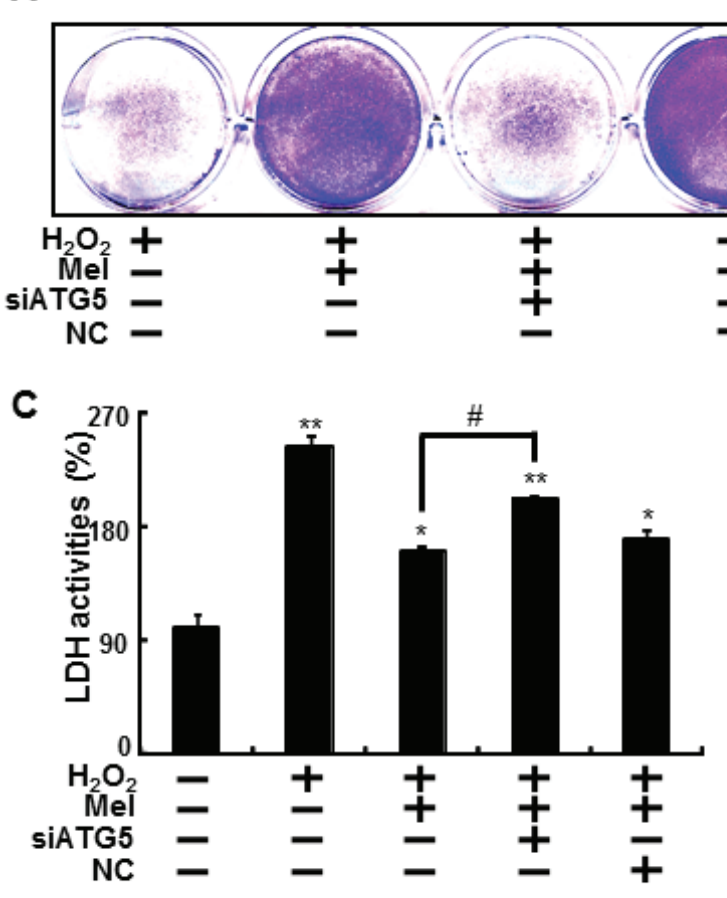

B

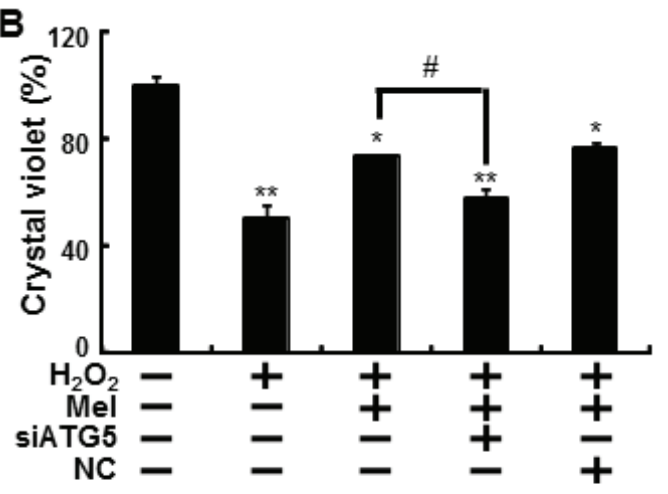

E

p62

\section{D}
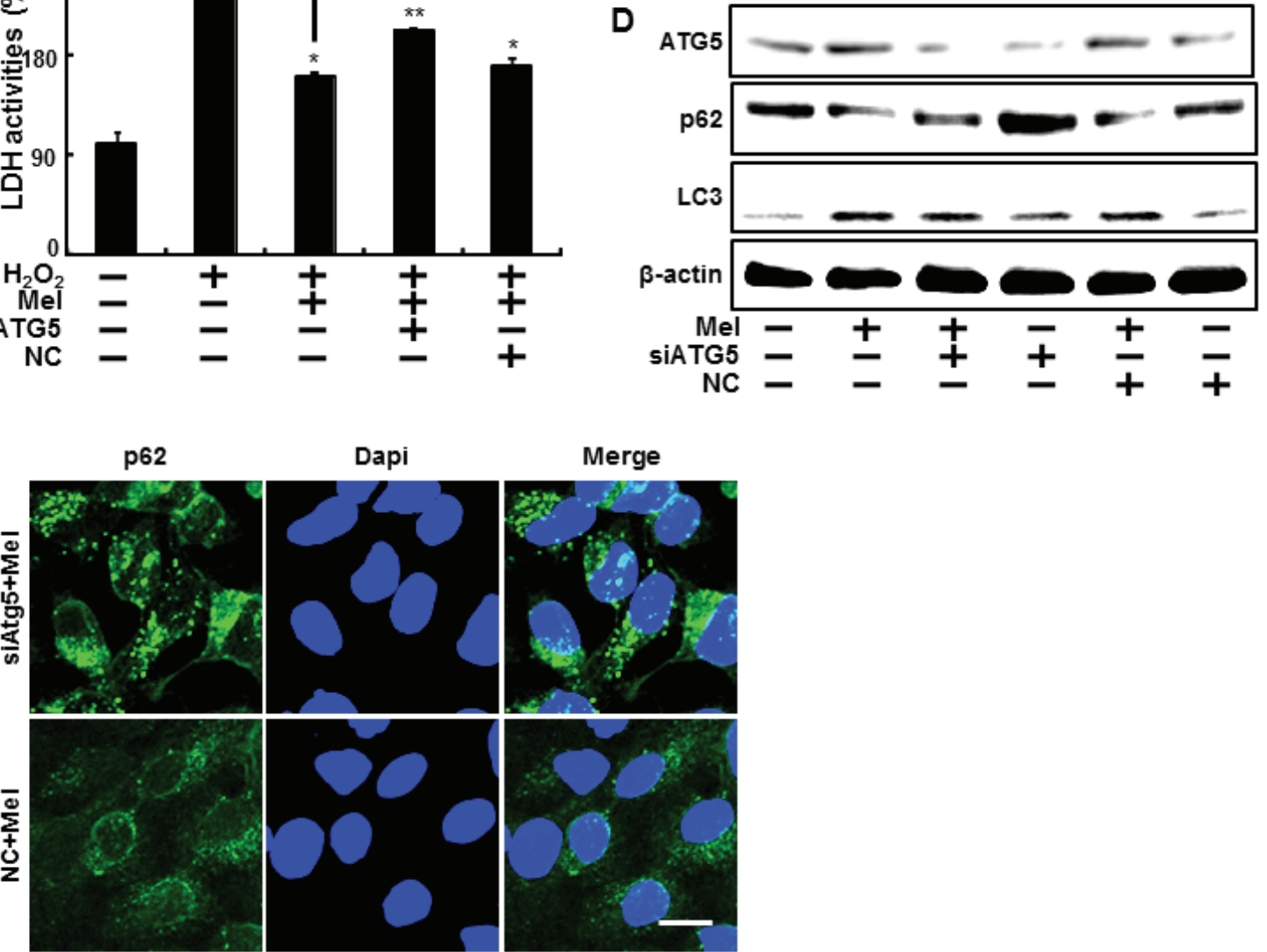

Dapi

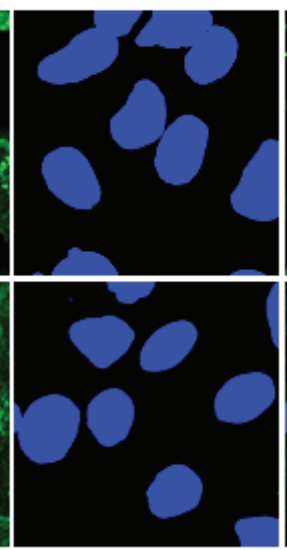

Merge

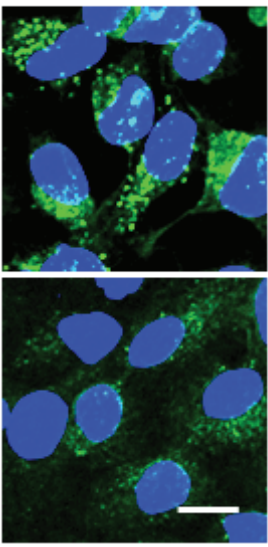

Figure 3: Inhibition of autophagy using ATG5 siRNA to counteract melatonin-related autophagy increases. ATG5 small interfering RNA (ATG5 siRNA) or negative control siRNA (NC siRNA) transfected HaCaT keratinocytes were incubated with $800 \mu \mathrm{M}$ $\mathrm{H}_{2} \mathrm{O}_{2}$ for $18 \mathrm{hr}$ in the presence of melatonin. Cell viability was measured using crystal violet staining. Viability of the control cells was set at $100 \%$ and viability relative to the control was measured A. B.. LDH activity was measured by quantifying LDH released in the medium C. ATG5 siRNA or NC siRNA transfected HaCaT keratinocytes were incubated with melatonin for 24 hr. Western blot analysis of LC3II and p62 proteins was conducted from the HaCaT keratinocytes. $\beta$-actin was used as a loading control D.. HaCaT keratinocytes were analyzed by immunocytochemistry for p62 E.. The cells were immunostained with p62 antibody (green) and observed in the fluorescent view. Scale bar: $10 \mu \mathrm{m}$. The bar graph indicates the mean \pm standard error of the mean (SEM) $(n=4) .{ }^{*} p<0.05$ and $* * p<0.01$, represent significant differences between the control and each treatment group and $\# p<0.01$; significantly different when compared with $\mathrm{H}_{2} \mathrm{O}_{2}$ and melatonin-treated group. 
as effective factor for $\mathrm{H}_{2} \mathrm{O}_{2}$ in keratinocytes was also examined. In the Figure 4 and 5, to verify the role of sirt1, we further tested the effects of melatonin on sirt1 using sirtinol (sirt1 inhibitor) and sirt1 siRNA.

HaCaT keratinocyte pretreated sirtinol with melatonin displayed a decrease of cell death and sirtinol did not change the cell viability in $\mathrm{H}_{2} \mathrm{O}_{2}$ treated cells (Figure 4A and 4B). And melatonin-induced reduction of LDH activities was inhibited by inactivation of sirt1 with sirtinol in LDH assay (Figure 4C). As shown in Figure4D, the expression levels of sirt1 were slightly decreased in treated melatonin after pretreating sirtinol and acetyl-p53 also showed differences in melatonin treatment and pretreating sirtinol.

In addition, melatonin effects on $\mathrm{H}_{2} \mathrm{O}_{2}$-induced cell damage were significantly reduced after sirt1 siRNA transfection in $\mathrm{H}_{2} \mathrm{O}_{2}$ treated cells (Figure 5A, 5B). And the effect on decreased $\mathrm{LDH}$ secretion from melatonin treatment was blocked by sirt1 siRNA transfection in $\mathrm{H}_{2} \mathrm{O}_{2}$ treated cells (Figure5C). In protein levels, the silencing of sirt1 with sirt1 siRNA reduced melatonininduced sirt1 increase, and restored acetyl-p53 to control levels (Figure 5D). Consequently, melatonin up-regulated sirt1 activity, and transfecting sirt1 siRNA blocked increased sirt1 activity caused by melatonin treatment. Sirt1 activity was not changed in the negative control (Figure 5E). Immunocytochemistry for sirtl showed the cells transfecting negative control exhibited the increased sirt1 levels by treatment of melatonin and sirt1 siRNAtransfected cells treated with melatonin showed attenuated the sirt1 expression (Figure 5F).

Our data suggested that melatonin could effectively enhance sirt1 expression and inhibition of sirt1 with sirtinol and sirtl siRNA led to reverse the melatonininduced increased cell viability in $\mathrm{H}_{2} \mathrm{O}_{2}$ treated cells.

We also investigated whether sirt 1 overexpression by adenoviral transfection also have protective effects on hydrogen peroxide. Consistent with melatonin treatment, Ad-sirt1 transfected cells increased the protective effects compared to Ad-LacZ transfected cells (Figure 6A-6C). And at multiplicity of infection (MOI) of 100-1000, Ad-sirt1 gradually increased sirt1 protein expression with protein levels at $100 \mathrm{MOI}$ (Figure 6D). We further investigated whether melatonin-induced sirtl as an important upstream intermediate of autophagy in HaCaT keratinocytes. Melatonin-induced autophagy was impaired
A

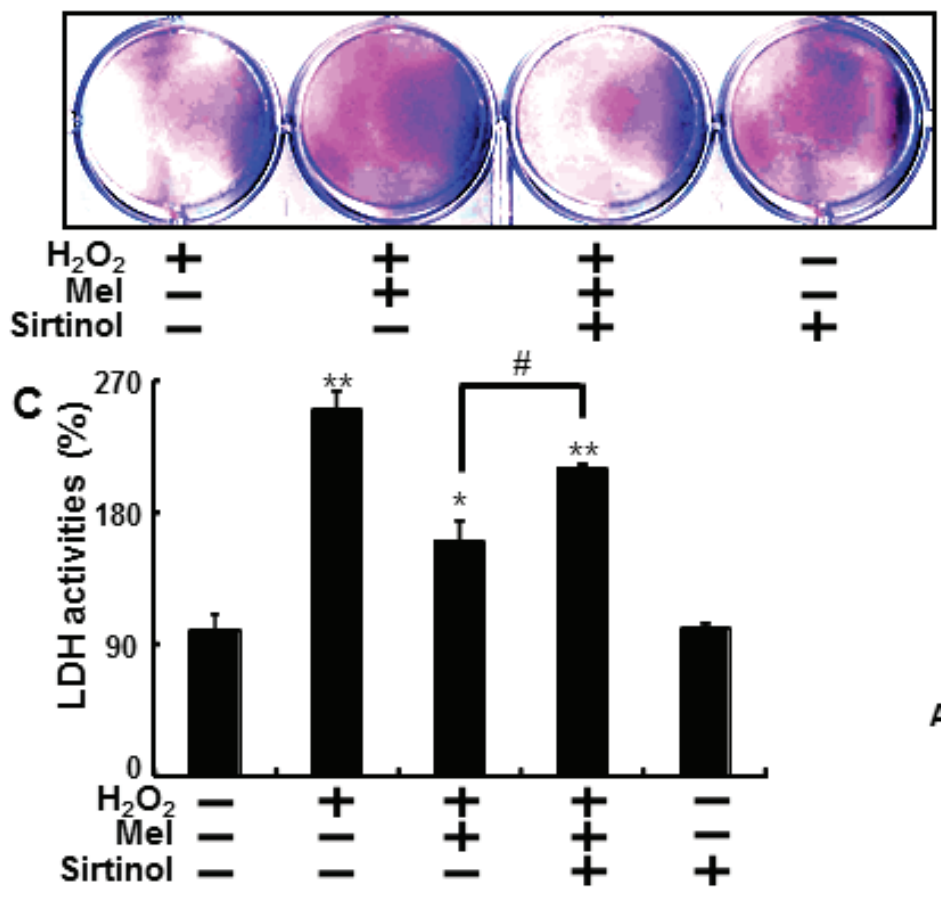

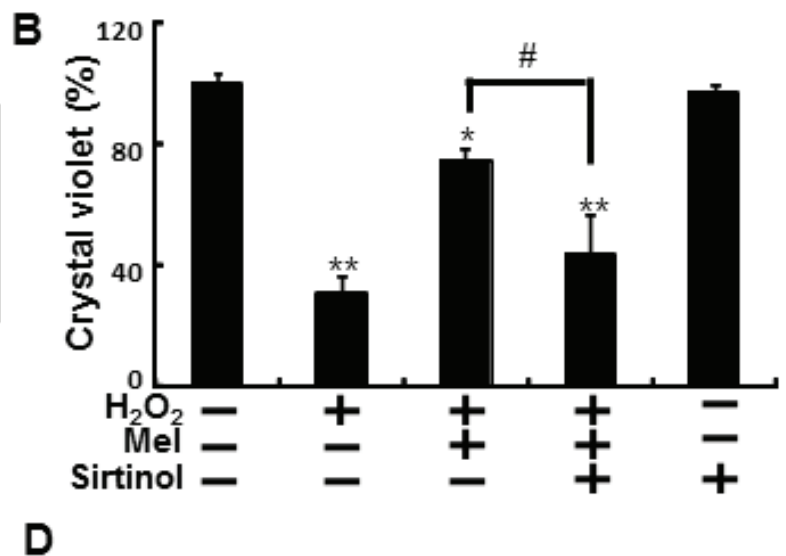

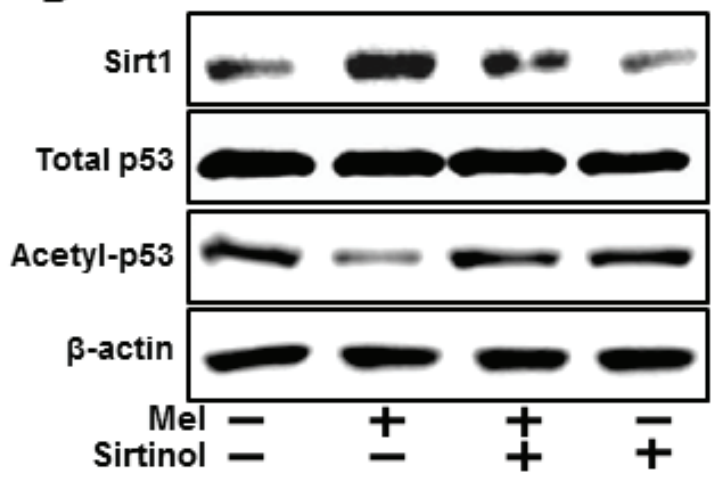

Figure 4: Inhibition of sirt1 activation by sirtinol reduced protective effects by melatonin against hydrogen peroxide. $\mathrm{HaCaT}$ keratinocytes were pre-incubated with melatonin $(10 \mu \mathrm{M})$ and exposed to $800 \mu \mathrm{M} \mathrm{H}_{2} \mathrm{O}_{2}$ for $18 \mathrm{hr}$ in the presence of sirtinol. The cell viability was measured by crystal violet staining. Viability of the control cells was set at $100 \%$, and viability relative to the control was measured A. B. LDH activities were measured by quantifying LDH released in the medium C. HaCaT keratinocytes were incubated with melatonin in the presence of sirtinol for $24 \mathrm{hr}$. Western blot for sirt 1 and acetyl-p53 proteins was analyzed from HaCaT keratinocytes. $\beta$-actin was used as loading control D. Bar graph indicates the mean \pm standard error of the mean (SEM) $(n=4)$. ${ }^{*} p<0.05, * * p<0.01$ significant differences between control and each treatment group and $\# p<0.01$; significantly different when compared with $\mathrm{H}_{2} \mathrm{O}_{2}$ and melatonin-treated group. 
by sirt1 inhibitor, sirtinol (Figure 7A). In addition, sirt1 siRNA significantly reversed the p62 reduction by melatonin treatment (Figure 7B). And also overexpression of sirt1 using adenovirus transfection reduced the p62 protein levels and enhanced LC3-II protein levels (Figure
7C). The results after the p62 antibody immunostaining of $\mathrm{HaCaT}$ keratinocytes also showed that melatonin-induced reduction of p62 protein was increased by silencing sirt1, and also overexpression of sirt1 also led to reduction of p62 protein levels (Figure 7D). These results indicate
A

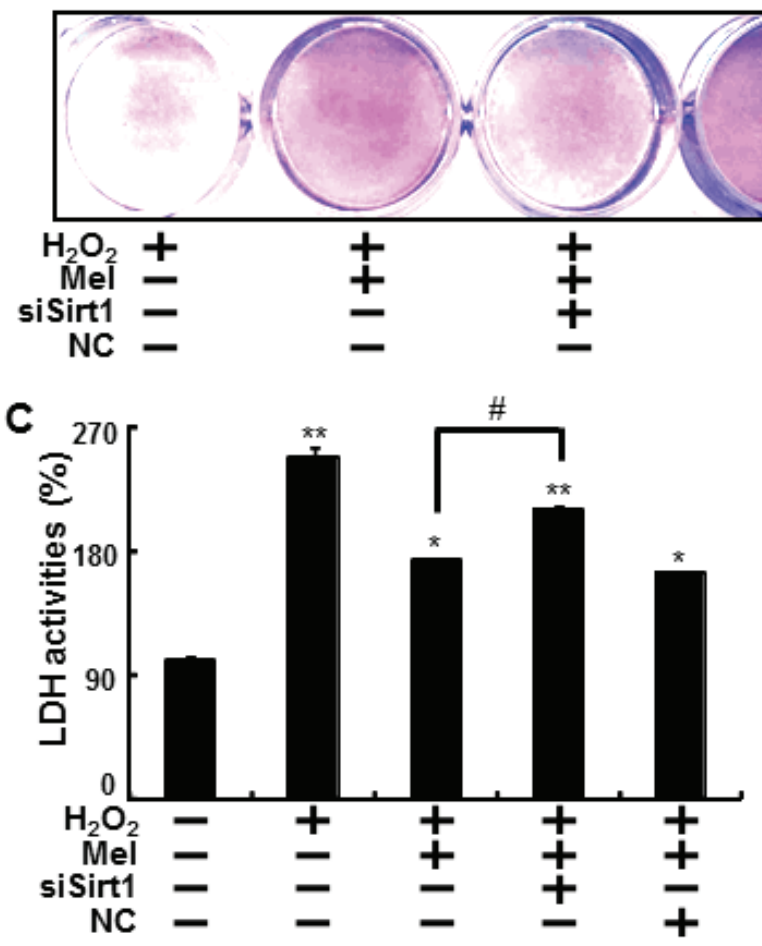

B

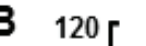

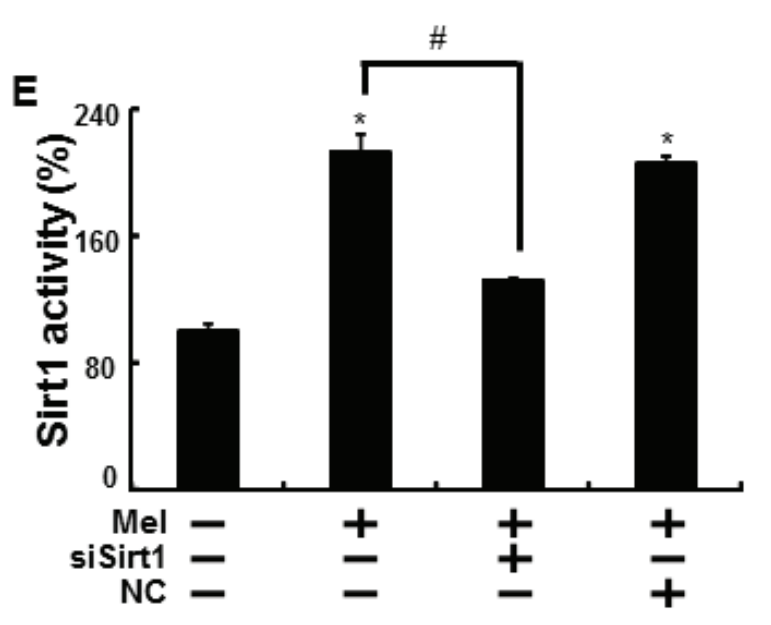

$\mathbf{F}$

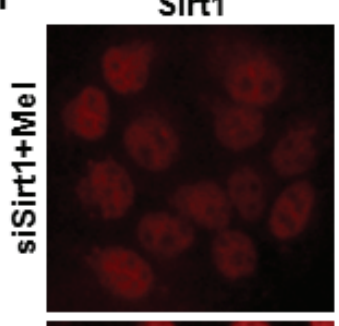

D

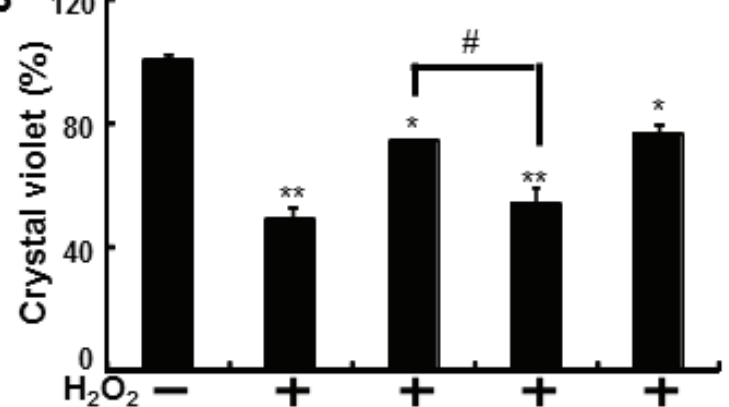
siSirt1 二 NC -
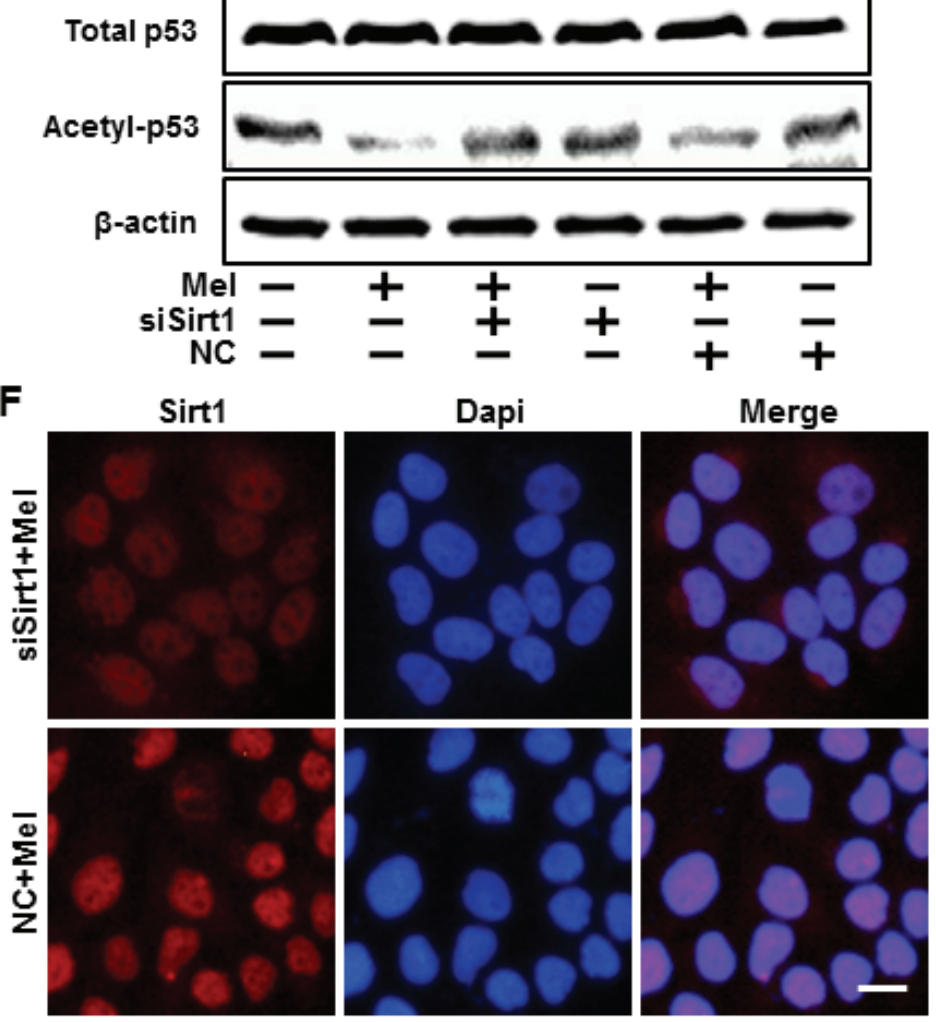

Figure 5: Blocking of sirt1 activity inhibited the melatonin-induced protection against hydrogen peroxide in keratinocyte. Sirt1 small interfering RNA (siSirt1) or negative control siRNA (NC siRNA) transfected HaCaT keratinocytes were incubated with $800 \mu \mathrm{M} \mathrm{H}_{2} \mathrm{O}_{2}$ for $18 \mathrm{hr}$ in the presence of melatonin. The cell viability was measured by crystal violet staining. Viability of the control cells was set at $100 \%$, and viability relative to the control was measured A., B. LDH activities were measured by quantifying LDH released in the medium C. siSirt1 or NC siRNA (negative control siRNA) transfected HaCaT keratinocytes were incubated with melatonin for $24 \mathrm{hr}$. Western blot for sirt1 and acetyl-p53 proteins was analyzed from HaCaT keratinocytes. $\beta$-actin was used as loading control D. Sirt1 deacetylase activities in nuclear were analyzed from HaCaT keratinocytes $\mathbf{E}$. The cells were immunostained with sirt1 antibody (red) and observed in the fluorescent view Scale bar: $10 \mu \mathrm{m} \mathrm{F}$. Bar graph indicates the mean \pm standard error of the mean (SEM) $(n=4) .{ }^{*} p<0.05,{ }^{*} p<0.01$ significant differences between control and each treatment group and $\# p<0.01$; significantly different when compared with $\mathrm{H}_{2} \mathrm{O}_{2}$ and melatonin-treated group. 
that melatonin-induced autophagy protects the human keratinocytes against hydrogen peroxide through sirt1 activation.

\section{DISCUSSION}

The primary goal of this study was to demonstrate the possibility that melatonin, a major product of the pineal gland $[70,71]$, may have a preventive effect on human keratinocytes exposed to hydrogen peroxide during the autophagy process via sirt1 activation.

Melatonin, known as $N$-acetyl-5-methoxytryptamine, demonstrates functionality as an important protective factor in various cells $[23,24,72]$. Melatonin by increasing Sirt1 activity and expression could enhance PGC-1 alpha function and mitochondrial biogenesis and function in cadmium-induced hepatotoxicity [73]. And also Sirt1 could have anti-inflammatory effects and cytoprotective effects enhanced by melatonin through the downregulation of PI3K/Akt, MAPKs, and NF- $\kappa \mathrm{B}$ signaling [74].

Many studies have focused on the role of melatonin in protecting against UVB-induced apoptosis and oxidative stress as well as seasonal reproduction and immune function $[75,76]$. However, it remains unclear whether melatonin prevents hydrogen peroxide-induced cell death and what, if any, protective action it exerts in keratinocytes. Melatonin has also been recognized as a potent scavenger of ROS that exhibits antioxidant effects through a free scavenging cascade and could prevent $\mathrm{H}_{2} \mathrm{O}_{2}$-induced cell damage and local inflammation in the adrenal medulla $[10,77]$. However, we were able to verify that, independently of the ROS process, melatonin influences keratinocytes damaged by hydrogen peroxide through autophagy.

The inhibition ofautophagysignificantly increases the generation of inflammatory cytokines and p62 expression in primary human keratinocytes [78]. Many reports have addressed the potential roles of autophagy, primarily those related to metabolic stress [79], in human keratinocyte differentiation [77]. Autophagy plays a major role in the degradation of cytoplasmic proteins in cells that are exposed to stressors that facilitate protein aggregation [80]. Protein degradation is induced by autophagy and an autophagosome-lysosome fusion is important in supplying amino acids in situations where there is nutrient starvation [81].

In Figure 3D, we demonstrate that $\mathrm{H}_{2} \mathrm{O}_{2}$ treatment led to autophagy dysfunction. Several previous studies
A

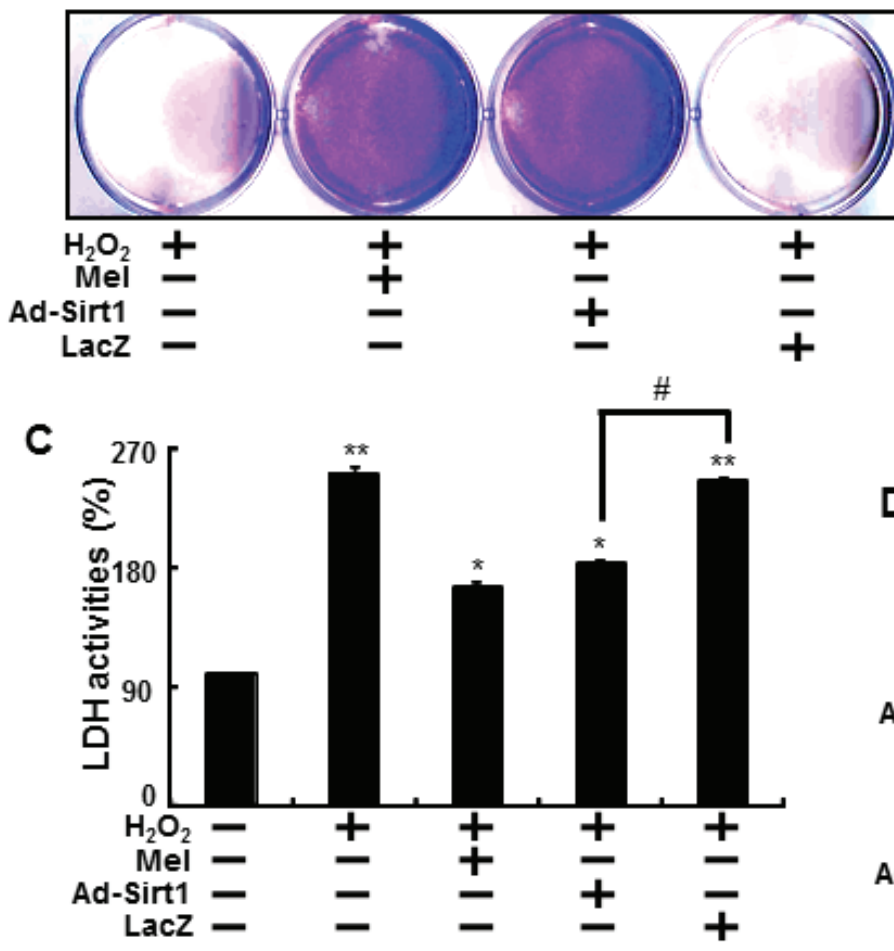

B
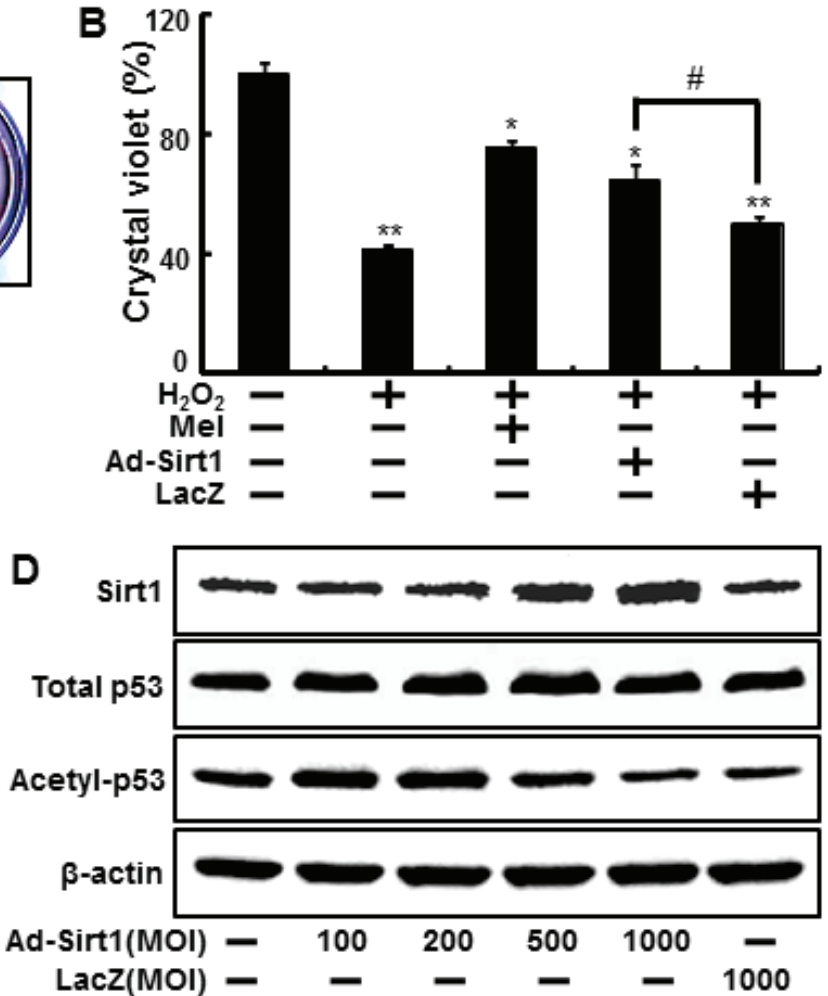

Figure 6: Overexpression of sirt1 increased protective effects against hydrogen peroxide in human keratinocytes. $\mathrm{HaCaT}$ keratinocyte was transfected by overexpressing adenovirus (Ad-Sirt1) or lacZ-bearing adenovirus (Ad-lacZ) and then exposed to $800 \mu \mathrm{M} \mathrm{H}_{2} \mathrm{O}_{2}$. Cell viability was measured by the Crystal violet assay. Viability of the control cells was set at $100 \%$, and viability relative to the control was measured A. B. LDH activities were measured by quantifying LDH released in the medium C. HaCaT keratinocyte was transfected by overexpressing adenovirus (Ad-Sirt1) or lacZ-bearing adenovirus (Ad-lacZ) for 24h. A Western blot for sirt1 and acetyl-p53 proteins was conducted from HaCaT keratinocytes. Beta-actin was used as the loading control D. Bar graph indicates the mean \pm standard error of the mean (SEM) $(n=4) . * p<0.05, * * p<0.01$ significant differences between control and each treatment group. 
A

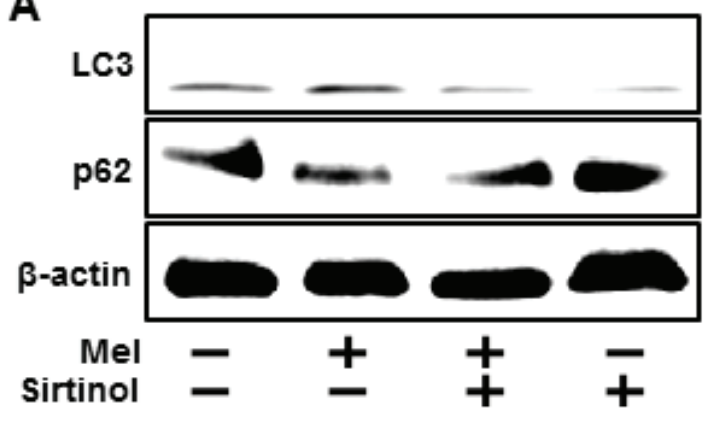

B

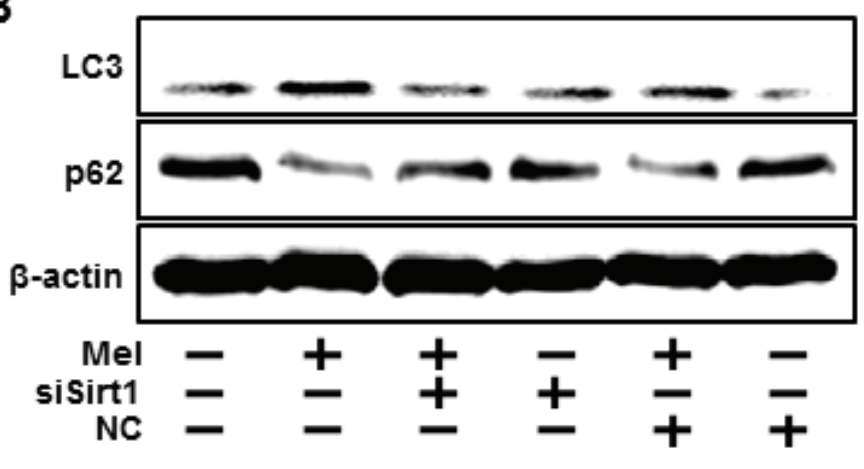

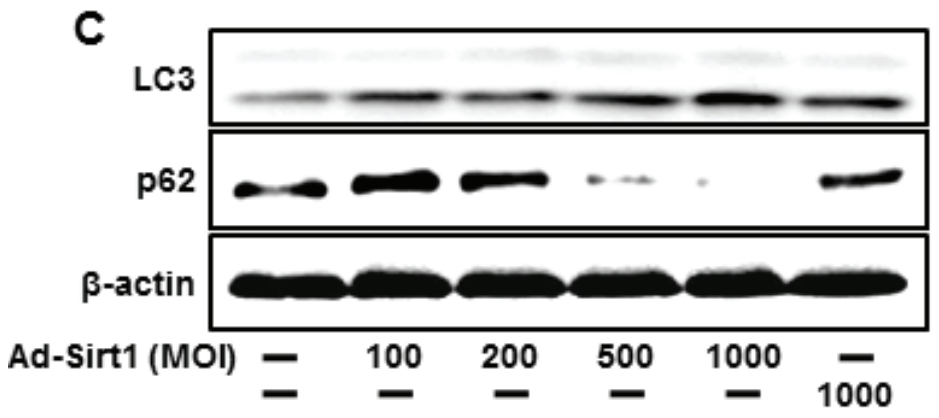

D
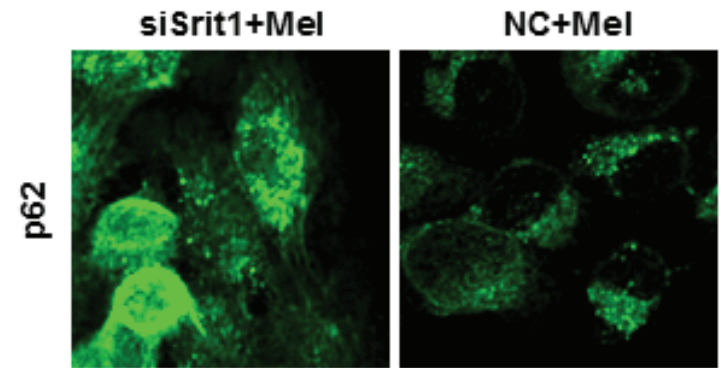

Ad-Sirt1

LacZ
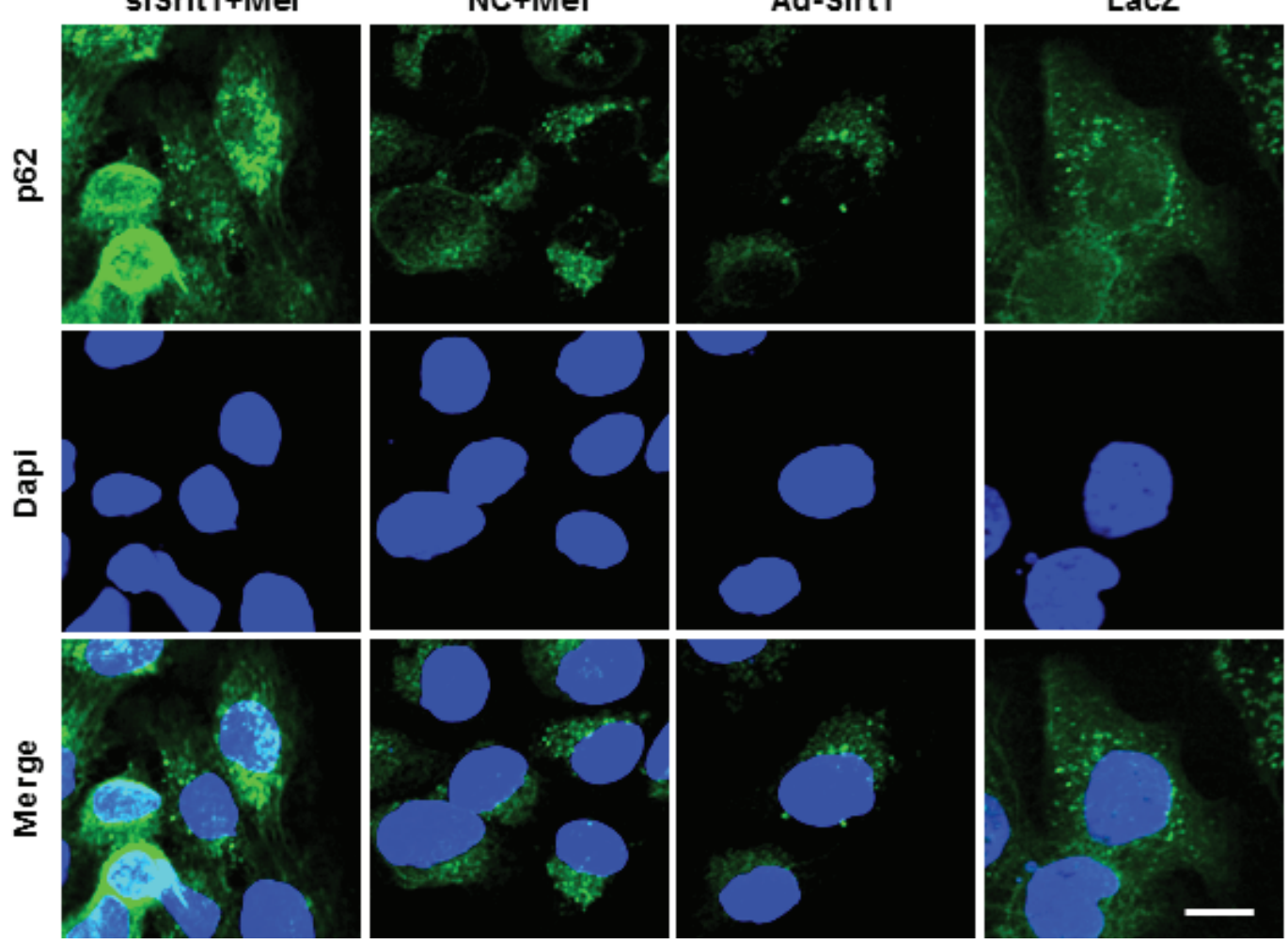

Figure 7: Blocking of sirt1 activity using siRNA and sirtinol inhibited the activation of autophagy flux by melatonin. $\mathrm{HaCaT}$ keratinocytes were incubated with melatonin in the presence of sirtinol for $24 \mathrm{hr}$. Total keratinocyte extracts were prepared and analyzed by Western blot for LC3-II and p62 protein levels A. Sirt1 small interfering RNA (siSirt1) or negative control siRNA (NC siRNA) transfected $\mathrm{HaCaT}$ keratinocytes were incubated with $10 \mu \mathrm{M}$ of melatonin. Western blot for LC3-II and p62 proteins was analyzed from $\mathrm{HaCaT}$ keratinocytes B. HaCaT keratinocyte was transfected by overexpressing adenovirus (Ad-Sirt1) or lacZ-bearing adenovirus (AdlacZ). Western blot for LC3-II and p62 proteins were analyzed from HaCaT keratinocytes $\mathbf{C}$. $\beta$-actin was used as loading control. The cells were immunostained with p62 antibody (green) and observed in the fluorescent view Scale bar: $10 \mu \mathrm{m}$ D. 
report that hydrogen peroxide enhances the induction of autophagy orautophagic cell death. However, autophagic processes triggered by hydrogen peroxide have not yet been conducted on human keratinocytes, so we cannot be certain of this result. Future studies are needed to analyze autophagy in response to hydrogen peroxide in human keratinocytes. And autophagy is in close connection with Sirt1 pathway. Many studies have shown that Sirt1 promotes autophagy-mediated processes which have positive effects for antiviral immune responses [82], cytotoxicity [83], hepatosteatosis [84] and kidney disease [85]. But relation of Sirt1 and autophagy in keratinocytes did not have been known.

In this study, we also did not confirm the effects of melatonin in primary keratinocytes. Consequently, protective effects of melatonin have yet to be demonstrated in primary human keratinocytes and mouse models. However, many possibilities exist for the use of melatonin as a protective agent against hydrogen peroxide in primary human keratinocytes. In an effort to clarify the potential use of melatonin as a protective tool, we plan to investigate whether melatonin exerts a protective effect against hydrogen peroxide as a result of sirt1/autophagy pathways in primary human keratinocytes and mouse models.

This study recognizes that the cellular and molecular mechanisms of melatonin-induced autophagy play a protective role through sirtl pathway against skin cell damage as a result of hydrogen peroxide-induced keratinocyte cell death. We suggest that melatonin may act as a therapeutic target in anti-cancer and anti-aging activities.

\section{MATERIALS AND METHODS}

\section{Cell culture}

HaCaT keratinocytes, an immortalized, nontumorigenic human keratinocyte cell line, were maintained in DMEM supplemented with 10\% FBS and $1 \%$ antibiotics at standard conditions $\left(37^{\circ} \mathrm{C}, 5 \% \mathrm{CO}_{2}\right.$, in a humidified incubator). For proliferation studies, $\mathrm{HaCaT}$ cells were seeded in $60-\mathrm{mm}$ culture dishes in standard medium or in the presence of different concentrations of melatonin $(1,2.5,5,10 \mu \mathrm{M})$ and $\mathrm{H}_{2} \mathrm{O}_{2}(100,200,400$, $800 \mu \mathrm{M})$. At appropriate intervals, triplicate dishes were trypsinized and cell numbers were determined by counting cell suspension in a Neubauer hemocytometer. Reported values represent the mean \pm S.D. of three independent samples at each experimental point.

\section{Crystal violet assay}

Cell viability was evaluated using crystal violet staining. Cells were briefly stained with a staining solution ( $0.5 \%$ crystal violet in $30 \%$ ethanoland $3 \%$ formaldehyde) for 10 minutes at room temperature (RT) and washed 4 times with water. The stained cells were lysed with $1 \%$ sodium dodecyl sulfate (SDS) and absorbance was measured at $550 \mathrm{~nm}$. Cell viability was calculated based on relative dye intensity as compared with the control.

\section{Lactate dehydrogenase (LDH) assay}

Cytotoxicitywas assessed in the supernatants using a LDH cytotoxicity detection kit (Takara Bio; Tokyo, Japan) according to manufacturer's instructions. LDH activity was determined by measuring the absorbance at 490nm using a Spectra Max M2 microplate reader (Molecular Devices; Sunnyvale, CA, USA).

\section{Western blot analysis}

After HaCaT keratinocytes were lysed in buffer (25 mM 4-(2-hydroxyethyl)-1-piperazineethanesulfonic acid, $100 \mathrm{mM} \mathrm{NaCl}, 1 \mathrm{mM}$ ethylenediaminetetraacetic acid, $5 \mathrm{mM} \mathrm{MgCl}, 0.1 \mathrm{mM}$ dithiothreitol and a protease inhibitor mixture at $\mathrm{pH}$ 7.4), proteins were electrophoretically resolved on $10-15 \%$ sodium dodecyl sulfate polyacrylamide gel and transferred to a nitrocellulose membrane. Immunoreactivity was detected through sequential incubations with horseradish peroxidase-conjugated secondary antibodies and enhanced chemiluminescence reagents. Antibodies used for immunoblotting included LC3 (Novus Biologicals, Littleton, CO, USA), p62 (Millipore, Bedford, MA, USA), autophagy related 5 (ATG5) (Abcam, Cambridge, MA, USA), SIRT1 (Santa Cruz Biotechnology), acetyl-p53 (Santa Cruz Biotechnology), and $\beta$-actin (Sigma Aldrich, St. Louis, MO, USA). Images were examined using a Fusion FX7 imaging system (Vilber Lourmat, Torcy Z.I. Sud, France).

\section{RNA interference}

HaCaT keratinocytes were transfected with ATG5 small interfering RNA (siRNA; oligoID HSS114104; Invitrogen, Carlsbad, CA, USA) and SIRT1 siRNA (oligoID VHS50608; Invitrogen) using Lipofectamine 2000 according to manufacturer's instructions. After a 48hour culture period, knockdown efficiency was typically measured at the protein level using immunoblot analysis. Nonspecific siRNA (oligoID 12935-300; Invitrogen) was used as a negative control. 


\section{Construction of recombinant adenoviruses}

The Sirt1 over-expressing adenovirus (Ad-Sirt1) was provided by Professor Byung-Hyun Park of Chonbuk National University (Jeonju, Jeonbuk, South Korea). The lacZ-bearing adenovirus (Ad-lacZ) was used as a control. Recombinant adenoviruses were amplified in human embryonic kidney (HEK)-293 cells and purified using the Vivapure AdenoPACK kit (Sartorius AG, Göttingen, Germany) according to manufacturer's instructions.

\section{Immunocytochemistry}

$\mathrm{HaCaT}$ keratinocytes were cultured on glass coverslips positioned on a 24 -well plate. Cells were washed withphosphatebuffered saline (PBS) and fixed with cold acetone for 90 seconds. Following this, cells were washed with PBS, blocked with 5\% FBS in Trisbuffered saline with Tween, and incubated with anti-p62 monoclonal antibodies $(2 \mu \mathrm{g} / \mathrm{mL})$ or anti-sirst 1 polyclonal antibodies $(5 \mu \mathrm{g} / \mathrm{mL})$ (for 48 hours at $\mathrm{RT}\left(20^{\circ} \mathrm{C}\right)$. Unbound antibody was removed with a PBS wash and cells were incubated with Alexa Fluor 488anti-mouse IgGantibody $(2 \mu \mathrm{g} / \mathrm{mL})$ or Alexa Fluor 546 anti-rabbit IgG antibody (2 $\mu \mathrm{g} / \mathrm{mL}$ ) for 2 hours at RT. Finally, cells were mounted with DakoCytomation fluorescent medium and visualized using afluorescence microscope.

\section{Sirt1 deacetylase activity assay}

To measure cellular Sirt1 deacetylase activity, nuclear proteins were extracted from $\mathrm{HaCaT}$ keratinocytes using a Nuclear/Cytosol Fractionation kit (BioVision, Milpitas, CA, USA). Sirt1 deacetylase activity was quantified following the protocols of the Sirt1 Fluorometric Assay kit (Sigma-Aldrich). Fluorescence intensities were measured with a microplate fluorometer (excitation wavelength $=360 \mathrm{~nm}$, emission wavelength $=$ $450 \mathrm{~nm}$ ). The fluorescence intensities of Sirt1 deacetylase activity were normalized to the protein levels measured in the cell samples.

\section{Statistical evaluation}

All data are expressed as the mean \pm standard deviation and were compared using Student'st-test, analysis of variance and Duncan's test using SAS statistical software version 9.1 (Version 9.1, SAS Institute, Cary, NC, USA). Results were considered significant at* $p<0.05, * * p<0.001$ and $\# p<0.01$ as appropriate.

\section{ACKNOWLEDGMENTS}

This study was supported by a grant from the National Research Foundation of Korea (NRF), funded by the Korean government (MISP) (2013R1A4A1069486) and Global Ph.D. Fellowship Program (2014H1A2A1021117).

\section{CONFLICTS OF INTEREST}

The authors declare no conflicts of interest.

\section{REFERENCES}

1. Barbouti A, Doulias PT, Nousis L, Tenopoulou M and Galaris D. DNA damage and apoptosis in hydrogen peroxide-exposed Jurkat cells: bolus addition versus continuous generation of $\mathrm{H}(2) \mathrm{O}(2)$. Free radical biology \& medicine. 2002; 33:691-702.

2. Sundaresan M, Yu ZX, Ferrans VJ, Irani K and Finkel T. Requirement for generation of $\mathrm{H} 2 \mathrm{O} 2$ for platelet-derived growth factor signal transduction. Science (New York, NY). 1995; 270:296-299.

3. Forman HJ and Torres M. Redox signaling in macrophages. Molecular aspects of medicine. 2001; 22:189-216.

4. Cao C, Lu S, Kivlin R, Wallin B, Card E, Bagdasarian A, Tamakloe T, Wang WJ, Song X, Chu WM, Kouttab N, Xu A and Wan Y. SIRT1 confers protection against UVBand $\mathrm{H} 2 \mathrm{O} 2$-induced cell death via modulation of p53 and JNK in cultured skin keratinocytes. Journal of cellular and molecular medicine. 2009; 13:3632-3643.

5. Gutteridge JM and Halliwell B. Free radicals and antioxidants in the year 2000. A historical look to the future. Annals of the New York Academy of Sciences. 2000; 899:136-147.

6. Applegate LA, Noel A, Vile G, Frenk E and Tyrrell RM. Two genes contribute to different extents to the heme oxygenase enzyme activity measured in cultured human skin fibroblasts and keratinocytes: implications for protection against oxidant stress. Photochemistry and photobiology. 1995; 61:285-291.

7. Lu CY, Lee HC, Fahn HJ and Wei YH. Oxidative damage elicited by imbalance of free radical scavenging enzymes is associated with large-scale mtDNA deletions in aging human skin. Mutation research. 1999; 423:11-21.

8. Kim KJ, Choi JS, Kang I, Kim KW, Jeong CH and Jeong JW. Melatonin suppresses tumor progression by reducing angiogenesis stimulated by HIF-1 in a mouse tumor model. Journal of pineal research. 2013; 54:264-270.

9. Singh $\mathrm{M}$ and Jadhav HR. Melatonin: functions and ligands. Drug discovery today. 2014; 19:1410-1418.

10. Bai J, Dong L, Song Z, Ge H, Cai X, Wang G and Liu $\mathrm{P}$. The role of melatonin as an antioxidant in human lens epithelial cells. Free radical research. 2013; 47:635-642.

11. Russcher M, Koch B, Nagtegaal E, van der Putten K, ter Wee $\mathrm{P}$ and Gaillard C. The role of melatonin treatment in chronic kidney disease. Frontiers in bioscience (Landmark 
edition). 2012; 17:2644-2656.

12. de Matos Cavalcante AG, de Bruin PF, de Bruin VM, Nunes DM, Pereira ED, Cavalcante MM and Andrade GM. Melatonin reduces lung oxidative stress in patients with chronic obstructive pulmonary disease: a randomized, double-blind, placebo-controlled study. Journal of pineal research. 2012; 53:238-244.

13. Scheuer C, Pommergaard HC, Rosenberg J and Gogenur I. Melatonin's protective effect against UV radiation: a systematic review of clinical and experimental studies. Photodermatology, photoimmunology \& photomedicine. 2014; 30:180-188.

14. Csaba G. The pineal regulation of the immune system: 40 years since the discovery. Acta microbiologica et immunologica Hungarica. 2013; 60:77-91.

15. Venegas C, Garcia JA, Escames G, Ortiz F, Lopez A, Doerrier C, Garcia-Corzo L, Lopez LC, Reiter RJ and Acuna-Castroviejo D. Extrapineal melatonin: analysis of its subcellular distribution and daily fluctuations. Journal of pineal research. 2012; 52:217-227.

16. Acuna-Castroviejo D, Escames G, Venegas C, DiazCasado ME, Lima-Cabello E, Lopez LC, Rosales-Corral S, Tan DX and Reiter RJ. Extrapineal melatonin: sources, regulation, and potential functions. Cellular and molecular life sciences. 2014; 71:2997-3025.

17. Favero G, Rodella LF, Reiter RJ and Rezzani R. Melatonin and its atheroprotective effects: a review. Molecular and cellular endocrinology. 2014; 382:926-937.

18. Marelli MM, Limonta P, Maggi R, Motta M and Moretti RM. Growth-inhibitory activity of melatonin on human androgen-independent DU 145 prostate cancer cells. The Prostate. 2000; 45:238-244.

19. Carrillo-Vico A, Guerrero JM, Lardone PJ and Reiter RJ. A review of the multiple actions of melatonin on the immune system. Endocrine. 2005; 27:189-200.

20. Tam CW, Mo CW, Yao KM and Shiu SY. Signaling mechanisms of melatonin in antiproliferation of hormonerefractory 22Rv1 human prostate cancer cells: implications for prostate cancer chemoprevention. Journal of pineal research. 2007; 42:191-202.

21. Mauriz JL, Collado PS, Veneroso C, Reiter RJ and Gonzalez-Gallego J. A review of the molecular aspects of melatonin's anti-inflammatory actions: recent insights and new perspectives. Journal of pineal research. 2013; 54:1-14.

22. Shiu SY, Leung WY, Tam CW, Liu VW and Yao KM. Melatonin MT1 receptor-induced transcriptional upregulation of $\mathrm{p} 27(\mathrm{Kip} 1)$ in prostate cancer antiproliferation is mediated via inhibition of constitutively active nuclear factor kappa B (NF-kappaB): potential implications on prostate cancer chemoprevention and therapy. Journal of pineal research. 2013; 54:69-79.

23. Tan DX, Manchester LC, Terron MP, Flores LJ and Reiter RJ. One molecule, many derivatives: a never-ending interaction of melatonin with reactive oxygen and nitrogen species? Journal of pineal research. 2007; 42:28-42.

24. Hardeland R, Cardinali DP, Srinivasan V, Spence DW, Brown GM and Pandi-Perumal SR. Melatonin--a pleiotropic, orchestrating regulator molecule. Progress in neurobiology. 2011; 93:350-384.

25. Janjetovic Z, Nahmias ZP, Hanna S, Jarrett SG, Kim TK, Reiter RJ and Slominski AT. Melatonin and its metabolites ameliorate ultraviolet B-induced damage in human epidermal keratinocytes. Journal of pineal research. 2014; 57:90-102.

26. Hipler UC, Fischer TW and Elsner P. HaCaT cell proliferation influenced by melatonin. Skin pharmacology and applied skin physiology. 2003; 16:379-385.

27. Bubenik GA. Thirty four years since the discovery of gastrointestinal melatonin. Journal of physiology and pharmacology. 2008; 59 Suppl 2:33-51.

28. Slominski A, Pisarchik A, Semak I, Sweatman T, Wortsman J, Szczesniewski A, Slugocki G, McNulty J, Kauser S, Tobin DJ, Jing $\mathrm{C}$ and Johansson O. Serotoninergic and melatoninergic systems are fully expressed in human skin. FASEB journal. 2002; 16:896-898.

29. She F, Wang W, Wang Y, Tang P, Wei J, Chen H and Zhang B. Melatonin protects MG63 osteoblast-like cells from hydrogen peroxide-induced cytotoxicity by maintaining mitochondrial function. Molecular medicine reports. 2014; 9:493-498.

30. Coto-Montes A, Boga JA, Rosales-Corral S, FuentesBroto L, Tan DX and Reiter RJ. Role of melatonin in the regulation of autophagy and mitophagy: a review. Molecular and cellular endocrinology. 2012; 361:12-23.

31. Vega-Naredo I, Caballero B, Sierra V, Garcia-Macia M, de Gonzalo-Calvo D, Oliveira PJ, Rodriguez-Colunga MJ and Coto-Montes A. Melatonin modulates autophagy through a redox-mediated action in female Syrian hamster Harderian gland controlling cell types and gland activity. Journal of pineal research. 2012; 52:80-92.

32. Choi SI, Kim KS, Oh JY, Jin JY, Lee GH and Kim EK. Melatonin induces autophagy via an mTOR-dependent pathway and enhances clearance of mutant-TGFBIp. Journal of pineal research. 2013; 54:361-372.

33. Nakagawa I, Amano A, Mizushima N, Yamamoto A, Yamaguchi H, Kamimoto T, Nara A, Funao J, Nakata M, Tsuda K, Hamada S and Yoshimori T. Autophagy defends cells against invading group A Streptococcus. Science (New York, NY). 2004; 306:1037-1040.

34. Paludan C, Schmid D, Landthaler M, Vockerodt M, Kube D, Tuschl T and Munz C. Endogenous MHC class II processing of a viral nuclear antigen after autophagy. Science (New York, NY). 2005; 307:593-596.

35. Tsukamoto S, Kuma A, Murakami M, Kishi C, Yamamoto A and Mizushima N. Autophagy is essential for preimplantation development of mouse embryos. Science (New York, NY). 2008; 321:117-120.

36. Fimia GM, Stoykova A, Romagnoli A, Giunta L, Di 
Bartolomeo S, Nardacci R, Corazzari M, Fuoco C, Ucar A, Schwartz P, Gruss P, Piacentini M, Chowdhury K and Cecconi F. Ambra1 regulates autophagy and development of the nervous system. Nature. 2007; 447:1121-1125.

37. Wang $\mathrm{K}$ and Klionsky DJ. Mitochondria removal by autophagy. Autophagy. 2011; 7:297-300.

38. Yorimitsu $\mathrm{T}$ and Klionsky DJ. Autophagy: molecular machinery for self-eating. Cell death and differentiation. 2005; 12 Suppl 2:1542-1552.

39. Puissant A, Fenouille N and Auberger P. When autophagy meets cancer through p62/SQSTM1. American journal of cancer research. 2012; 2:397-413.

40. Mathew R, Karp CM, Beaudoin B, Vuong N, Chen G, Chen HY, Bray K, Reddy A, Bhanot G, Gelinas C, Dipaola RS, Karantza-Wadsworth V and White E. Autophagy suppresses tumorigenesis through elimination of p62. Cell. 2009; 137:1062-1075.

41. Ravikumar B, Sarkar S, Davies JE, Futter M, GarciaArencibia M, Green-Thompson ZW, Jimenez-Sanchez M, Korolchuk VI, Lichtenberg M, Luo S, Massey DC, Menzies FM, Moreau K, Narayanan U, Renna M, Siddiqi FH, et al. Regulation of mammalian autophagy in physiology and pathophysiology. Physiological reviews. 2010; 90:13831435.

42. Rubinsztein DC, Marino G and Kroemer G. Autophagy and aging. Cell. 2011; 146:682-695.

43. Klionsky DJ. Autophagy: from phenomenology to molecular understanding in less than a decade. Nature reviews Molecular cell biology. 2007; 8:931-937.

44. Yang Z and Klionsky DJ. Mammalian autophagy: core molecular machinery and signaling regulation. Current opinion in cell biology. 2010; 22:124-131.

45. Hara T, Nakamura K, Matsui M, Yamamoto A, Nakahara Y, Suzuki-Migishima R, Yokoyama M, Mishima K, Saito I, Okano H and Mizushima N. Suppression of basal autophagy in neural cells causes neurodegenerative disease in mice. Nature. 2006; 441:885-889.

46. Levine B and Kroemer G. Autophagy in the pathogenesis of disease. Cell. 2008; 132:27-42.

47. Haigis MC and Guarente LP. Mammalian sirtuins-emerging roles in physiology, aging, and calorie restriction. Genes \& development. 2006; 20:2913-2921.

48. Imai S, Armstrong CM, Kaeberlein M and Guarente L. Transcriptional silencing and longevity protein Sir2 is an NAD-dependent histone deacetylase. Nature. 2000; 403:795-800.

49. Fulco M, Schiltz RL, Iezzi S, King MT, Zhao P, Kashiwaya Y, Hoffman E, Veech RL and Sartorelli V. Sir2 regulates skeletal muscle differentiation as a potential sensor of the redox state. Molecular cell. 2003; 12:51-62.

50. Picard F, Kurtev M, Chung N, Topark-Ngarm A, Senawong T, Machado De Oliveira R, Leid M, McBurney MW and Guarente L. Sirt1 promotes fat mobilization in white adipocytes by repressing PPAR-gamma. Nature. 2004;
429:771-776.

51. Rodgers JT, Lerin C, Haas W, Gygi SP, Spiegelman BM and Puigserver P. Nutrient control of glucose homeostasis through a complex of PGC-1alpha and SIRT1. Nature. 2005; 434:113-118.

52. Bordone L, Motta MC, Picard F, Robinson A, Jhala US, Apfeld J, McDonagh T, Lemieux M, McBurney M, Szilvasi A, Easlon EJ, Lin SJ and Guarente L. Sirt1 regulates insulin secretion by repressing UCP2 in pancreatic beta cells. PLoS biology. 2006; 4:e31.

53. Blander G, Bhimavarapu A, Mammone T, Maes D, Elliston K, Reich C, Matsui MS, Guarente L and Loureiro JJ. SIRT1 promotes differentiation of normal human keratinocytes. The Journal of investigative dermatology. 2009; 129:41-49.

54. Dal Farra C and Domloge N. SIRT1, the human homologue to SIR2, is expressed in human skin and in cultured keratinocytes fibroblasts and $\mathrm{HaCaT}$ cells; and its levels is closely related to stress and aging. Journal of cosmetic science. 2006; 57:187-188.

55. Yang Y, Duan W, Li Y, Jin Z, Yan J, Yu S and Yi D. Novel role of silent information regulator 1 in myocardial ischemia. Circulation. 2013; 128:2232-2240.

56. Yang Y, Duan W, Li Y, Yan J, Yi W, Liang Z, Wang N, Yi $\mathrm{D}$ and Jin $\mathrm{Z}$. New role of silent information regulator 1 in cerebral ischemia. Neurobiology of aging. 2013; 34:28792888 .

57. Luo J, Nikolaev AY, Imai S, Chen D, Su F, Shiloh A, Guarente L and $\mathrm{Gu}$ W. Negative control of p53 by Sir2alpha promotes cell survival under stress. Cell. 2001; 107:137148.

58. Vaziri H, Dessain SK, Ng Eaton E, Imai SI, Frye RA, Pandita TK, Guarente L and Weinberg RA. hSIR2(SIRT1) functions as an NAD-dependent p53 deacetylase. Cell. 2001; 107:149-159.

59. Xu F, Yan JH, Liang H, Xu W, Ye JP and Weng JP. SIRT1 knockout impairs the differentiation of adipocyte in C57BL/6J mice and its underlying mechanism. [Article in Chinese]. Zhonghua yi xue za zhi. 2013; 93:2857-2860.

60. Bouras T, Fu M, Sauve AA, Wang F, Quong AA, Perkins ND, Hay RT, Gu W and Pestell RG. SIRT1 deacetylation and repression of p300 involves lysine residues 1020/1024 within the cell cycle regulatory domain 1 . The Journal of biological chemistry. 2005; 280:10264-10276.

61. Brunet A, Bonni A, Zigmond MJ, Lin MZ, Juo P, Hu LS, Anderson MJ, Arden KC, Blenis J and Greenberg ME. Akt promotes cell survival by phosphorylating and inhibiting a Forkhead transcription factor. Cell. 1999; 96:857-868.

62. Motta MC, Divecha N, Lemieux M, Kamel C, Chen D, Gu W, Bultsma Y, McBurney M and Guarente L. Mammalian SIRT1 represses forkhead transcription factors. Cell. 2004; 116:551-563.

63. Kim $\mathrm{CH}$, Kim $\mathrm{KH}$ and Yoo YM. Melatonin-induced autophagy is associated with degradation of MyoD protein in C2C12 myoblast cells. Journal of pineal research. 2012; 
$53: 289-297$

64. Wang XY, He PY, Du J and Zhang JZ. Quercetin in combating $\mathrm{H} 2 \mathrm{O} 2$ induced early cell apoptosis and mitochondrial damage to normal human keratinocytes. Chinese medical journal. 2010; 123:532-536.

65. Cao C, Lu S, Kivlin R, Wallin B, Card E, Bagdasarian A, Tamakloe T, Chu WM, Guan KL and Wan Y. AMPactivated protein kinase contributes to UV- and $\mathrm{H} 2 \mathrm{O} 2$ induced apoptosis in human skin keratinocytes. The Journal of biological chemistry. 2008; 283:28897-28908.

66. Fischer TW, Zbytek B, Sayre RM, Apostolov EO, Basnakian AG, Sweatman TW, Wortsman J, Elsner P and Slominski A. Melatonin increases survival of $\mathrm{HaCaT}$ keratinocytes by suppressing UV-induced apoptosis. Journal of pineal research. 2006; 40:18-26.

67. Nickel A and Wohlrab W. Melatonin protects human keratinocytes from UVB irradiation by light absorption. Archives of dermatological research. 2000; 292:366-368.

68. Lee HJ, Lee HJ, Sohn EJ, Lee EO, Kim JH, Lee MH and Kim SH. Inhibition of Connexin 26/43 and ExtracellularRegulated Kinase Protein Plays a Critical Role in Melatonin Facilitated Gap Junctional Intercellular Communication in Hydrogen Peroxide-Treated HaCaT Keratinocyte Cells. Evidence-based complementary and alternative medicine. 2012; 2012:589365.

69. Chen J, Wang L, Wu C, Hu Q, Gu C, Yan F, Li J, Yan $\mathrm{W}$ and Chen G. Melatonin-enhanced autophagy protects against neural apoptosis via a mitochondrial pathway in early brain injury following a subarachnoid hemorrhage. Journal of pineal research. 2014; 56:12-19.

70. Lewy AJ, Wehr TA, Goodwin FK, Newsome DA and Markey SP. Light suppresses melatonin secretion in humans. Science (New York, NY). 1980; 210:1267-1269.

71. Vanecek J. Cellular mechanisms of melatonin action. Physiological reviews. 1998; 78(3):687-721.

72. Luchetti F, Canonico B, Betti M, Arcangeletti M, Pilolli F, Piroddi M, Canesi L, Papa S and Galli F. Melatonin signaling and cell protection function. FASEB journal. 2010; 24:3603-3624.

73. Guo P, Pi H, Xu S, Zhang L, Li Y, Li M, Cao Z, Tian L, Xie J, Li R, He M, Lu Y, Liu C, Duan W, Yu Z and Zhou Z. Melatonin Improves mitochondrial function by promoting MT1/SIRT1/PGC-1 alpha-dependent mitochondrial biogenesis in cadmium-induced hepatotoxicity in vitro. Toxicological sciences. 2014; 142:182-195.

74. Lim HD, Kim YS, Ko SH, Yoon IJ, Cho SG, Chun YH, Choi BJ and Kim EC. Cytoprotective and anti-inflammatory effects of melatonin in hydrogen peroxide-stimulated CHON-001 human chondrocyte cell line and rabbit model of osteoarthritis via the SIRT1 pathway. Journal of pineal research. 2012; 53:225-237.

75. Slominski RM, Reiter RJ, Schlabritz-Loutsevitch N, Ostrom RS and Slominski AT. Melatonin membrane receptors in peripheral tissues: distribution and functions. Molecular and cellular endocrinology. 2012; 351:152-166.

76. Reiter RJ. Pineal melatonin: cell biology of its synthesis and of its physiological interactions. Endocrine reviews. 1991; 12:151-180.

77. Hardeland R, Tan DX and Reiter RJ. Kynuramines, metabolites of melatonin and other indoles: the resurrection of an almost forgotten class of biogenic amines. Journal of pineal research. 2009; 47:109-126.

78. Lee HM, Shin DM, Yuk JM, Shi G, Choi DK, Lee SH, Huang SM, Kim JM, Kim CD, Lee JH and Jo EK. Autophagy negatively regulates keratinocyte inflammatory responses via scaffolding protein p62/SQSTM1. Journal of immunology. 2011; 186:1248-1258.

79. Wang RC and Levine B. Calcipotriol induces autophagy in HeLa cells and keratinocytes. The Journal of investigative dermatology. 2011; 131:990-993.

80. Tyedmers J, Mogk A and Bukau B. Cellular strategies for controlling protein aggregation. Nature reviews Molecular cell biology. 2010; 11:777-788.

81. Sukseree S, Eckhart L, Tschachler E and Watanapokasin R. Autophagy in epithelial homeostasis and defense. Frontiers in bioscience (Elite edition). 2013; 5:1000-1010.

82. Owczarczyk AB, Schaller MA, Reed M, Rasky AJ, Lombard DB and Lukacs NW. Sirtuin 1 Regulates Dendritic Cell Activation and Autophagy during Respiratory Syncytial Virus-Induced Immune Responses. Journal of immunology. 2015; 195:1637-1646.

83. Jiang W, Zhang X, Hao J, Shen J, Fang J, Dong W, Wang D, Zhang X, Shui W, Luo Y, Lin L, Qiu Q, Liu B and $\mathrm{Hu}$ Z. SIRT1 protects against apoptosis by promoting autophagy in degenerative human disc nucleus pulposus cells. Scientific reports. 2014; 4:7456.

84. Song YM, Lee YH, Kim JW, Ham DS, Kang ES, Cha BS, Lee HC and Lee BW. Metformin alleviates hepatosteatosis by restoring SIRT1-mediated autophagy induction via an AMP-activated protein kinase-independent pathway. Autophagy. 2015; 11:46-59.

85. Yacoub R, Lee K and He JC. The Role of SIRT1 in Diabetic Kidney Disease. Frontiers in endocrinology. 2014; 5:166. 